\title{
VIDA E OBRA DE ÁLVARO VIEIRA PINTO: UM LEVANTAMENTO BIOBIBLIOGRÁFICO ${ }^{1}$
}

\author{
Rodrigo Freese Gonzatto \\ Universidade Tecnológica Federal do Paraná (UTFPR) \\ Pontifícia Universidade Católica do Paraná (PUCPR) \\ Luiz Ernesto Merkle \\ Universidade Tecnológica Federal do Paraná (UTFPR)
}

\section{RESUMO}

Este artigo traça um breve levantamento biográfico de Álvaro Borges Vieira Pinto (Campos dos Goytacazes, RJ, 1909 - Rio de Janeiro, RJ, 1987) e apresenta uma bibliografia atualizada de sua produção intelectual, trazendo novas informações e retificando algumas datas e referências. Vieira Pinto, intelectual de formação interdisciplinar, foi professor, médico, pesquisador e filósofo. Embora seja ocasionalmente apontado apenas como pensador "desenvolvimentista", devido a sua ligação com o Instituto Superior de Estudos Brasileiros (ISEB), nas últimas décadas vem sendo reconhecido por suas lições sobre a educação de adultos, seu livro sobre o método científico, e, mais recentemente, por suas reflexões sobre as tecnologias. Como sua obra ainda é pouco conhecida e de difícil acesso, delineamos sua produção intelectual para melhor estudá-la, difundi-la e disponibilizá-la. Partimos de esforços, já realizados anteriormente, de revisão sobre sua obra, que compilamos, organizamos, indexamos e complementamos, buscando uma compreensão abrangente da obra de Vieira Pinto, como parte de um esforço de longo prazo, visando organizar um acervo digital de referência sobre este autor, que permita contribuir para sua releitura, difusão e circulação. Palavras-chave: Álvaro Vieira Pinto; ISEB; bibliografia; biografia.

\section{LIFE AND WORK OF ÁLVARO VIEIRA PINTO: A BIOBIBLIOGRAPHIC SURVEY}

\begin{abstract}
This article is a brief bibliographical survey of Álvaro Borges Vieira Pinto (Campos dos Goytacazes, RJ, 1909 - Rio de Janeiro, RJ, 1987) and features an updated bibliography of his intellectual production, bringing new information and correcting some dates and references. Vieira Pinto, intellectual with interdisciplinar education, worked as teacher, doctor, researcher and philosopher. Although occasionally touted just as a thinker "developmentalist", due to its connection with the Superior Institute of Brazilian Studies (ISEB), in the last decades has been recognized for his lessons on adult education, his book about the scientific method, and, more recently, for his reflections over technologies. As his work is still little known and difficult to access, we outlined his intellectual production to better study it, spread it and make it available. We started from efforts already made of reviewing his work which we compiled, organized, indexed and complement, seeking a extensive understanding of the work of Vieira Pinto, as part of a long-term effort, in order to organize a digital reference collection of this author allowing to contribute to its reinterpretation, dissemination and circulation.
\end{abstract}

Keywords: Álvaro Vieira Pinto; ISEB; bibliography; biography. 


\section{Apresentação}

Álvaro Vieira Pinto foi um pensador brasileiro, autor de vasta e profunda produção intelectual, que ainda necessita ser revisitado, debatido e aprofundado. Conhecido pela influencia que suas ideias exerceram nas concepções de educação e pedagogia crítica de Paulo Freire ${ }^{2}$, o impacto de sua obra é notadamente mais amplo. Vieira Pinto participou dos grandes debates de sua época, foi uma referência para estudantes e intelectuais de sua geração, e nos deixou um legado que, apesar da tentativa de apagamento realizada durante a ditadura brasileira, ainda hoje oferece contribuições para a práxis na condição de subdesenvolvimento.

De formação plural, poliglota e violinista amador, o pensador atuou como filósofo, professor, cientista, tradutor e foi autor de trabalhos em diversas áreas e temáticas, como filosofia, educação, trabalho, demografia, ciência, terceiro mundo, tecnologia e cibernética. Atualmente identificamos obras de sua autoria de 1928 a $1975^{3}$. Entretanto, nem todos seus escritos foram publicados, e muitos são de difícil acesso. Apenas algumas de suas obras estão disponíveis em formato digital (digitalizadas como fac-símile) e quase a totalidade é encontrada exclusivamente em edição impressa. Atualmente, em 2016, apenas quatro obras estão à venda em livrarias ${ }^{4}$ e o restante se encontra disponível somente via bibliotecas e sebos, por estarem à décadas sem receber novas edições ou reimpressões. Algumas obras foram publicadas somente em outros países e outras foram escritas apenas em espanhol, sem nunca terem sido traduzidas para o português ou publicadas no Brasil. Existem inclusive manuscritos inéditos, mencionados pelo autor em entrevista ${ }^{5}$, mas que possuem destino incerto por não terem sido resgatados até o momento.

Mesmo assim, nos últimos anos, vemos crescer a pesquisa sobre Álvaro Vieira Pinto e a que utiliza o autor como referencial teórico, com a publicação de novas teses, dissertações, trabalhos de conclusão de curso, resenhas e artigos. Temos hoje importantes obras de compreensão e de análise da vida e obra de Vieira Pinto, como os livros de Vanilda Pereira Paiva (1980), Lidia Maria Rodrigo (1988), Jorge Roux (1990), Marcos Cezar de Freitas (1998), Norma Côrtes (2003), José Ernesto de Fáveri (2012; 2014), dentre outras pessoas, que reconheceram por suas pesquisas a importância deste autor, favorecendo uma recente releitura e redescoberta de sua obra. Ao estudar tal literatura, atentamos com a dificuldade em encontrar as publicações mencionadas, quando também nos deparamos com referências distintas para uma mesma obra ou acontecimento, ou a certa imprecisão em suas datas de edição ou ocorrência. O esforço de pesquisa, recuperação, catalogação e indexação que o recenseamento bibliográfico apresentado neste artigo oferece, visa a contribuir na continuidade de renovação da recepção deste autor e de sua obra, facilitando assim a sua citação e recuperação.

A sistematização que este artigo expressa reconhece que sua obra ainda permanece de difícil acesso e tímida circulação. Como já mencionado, ainda são escassos os materiais acessíveis sobre Vieira Pinto, especialmente em formatos sintéticos e de acesso rápido, que ajudem novos leitores e novas leitoras a uma introdução abrangente do estudo do seu pensamento e de sua biografia, abarcando com mais precisão a amplitude de sua produção. Com a finalidade de auxiliar estudos e pesquisas sobre e a partir da obra de Álvaro Vieira Pinto e facilitar sua referência, desenvolvemos esta biobibliografia como um material digi$\operatorname{tal}^{6}$ (que permite realizar busca por palavras e copiar trechos), aberto (com licença pública ${ }^{7}$ e disponível em repositório de acesso aberto), com referências organizadas de modo sistemático (todas as afirmações sobre vida e obra do autor estão referenciadas em notas de rodapé, citando a página da fonte da informação) e que possibilita a consulta de uma ampla quantidade de informações. 
Para um panorama geral de acontecimentos da vida e da produção intelectual de Álvaro Vieira Pinto partimos dos esforços de revisão da produção intelectual do autor que já foram realizados anteriormente, mencionados acima. Buscamos atualizar e complementar informações bibliográficas do autor, concentrando-as em um único local. Esta necessidade surgiu de nossas próprias pesquisas, por ser necessário aprofundar nosso conhecimento sobre o pensador brasileiro ou indicar textos para utilização em sala de aula e em grupos de estudos. Não temos como objetivo substituir as obras que utilizamos como referência para este artigo, pois trazem outras reflexões de suma importância para uma compreensão renovada do autor. Ao contrário, buscamos evidenciar a importância do trabalho de pesquisa destes autores e autoras, assim como sua relevância para a investigação aprofundada e rigorosa na obra de Vieira Pinto, fundamentais para sua análise adequada. Desta forma, este trabalho não pretende ser uma análise da vida e obra do autor, mas pode ser ponto de partida, que deve estar sempre em atualização e reconstrução.

\subsection{Metodologia}

Por este se tratar de um artigo com tamanho limitado para essa exposição, centraremos nossas referências nas principais referências biográficas e bibliográficas, sem apresentar uma contextualização histórica mais ampla, certamente necessária para uma compreensão mais abrangente da vida e obra de Vieira Pinto. Utilizamos como principal referência para esta pesquisa o trabalho de autores e autoras que já estudaram a vida e a obra de Vieira Pinto. Também utilizamos algumas outras fontes, que nos auxiliaram a retificar algumas datas, ou que complementaram a trajetória do filósofo com novas informações, ausentes nas descrições até então relatadas, que tivemos conhecimento.

Durante muito tempo as ideias de Álvaro Vieira Pinto foram lidas principalmente a partir da sua obra "Consciência e Realidade Nacional", ao menos no Brasil ${ }^{8}$. Mesmo sendo fundamental para a compreensão de seu pensamento, não é possível ter nesta única obra a síntese de suas ideias, consideração esta comentada por Freitas (1996, p.20-21) e que se manifesta em obras recentes sobre a trajetória intelectual de Vieira Pinto. Assim, a recepção da produção intelectual de Vieira Pinto vem assumindo outros contornos, com a difusão do debate em torno de "Sete lições sobre educação de adultos", a retomada da leitura de "Ciência e Existência" em cursos de pós-graduação e, mais atualmente, da publicação póstuma do livro "O Conceito de Tecnologia" e "A Sociologia dos Países Subdesenvolvidos", como é possível observar com o crescimento recente de publicações sobre o autor. Outra motivação para tal, é que muitas das obras de Vieira Pinto não possuem novas tiragens. "Consciência e Realidade Nacional", por exemplo, não é reeditada e não é republicada deste sua primeira edição, de 1960.

Várias são as formas possíveis de estruturar uma narrativa para se compreender a produção de Álvaro Vieira Pinto. Por exemplo, Marcos Cezar de Freitas (1998) resgata a trajetória intelectual e política de Vieira Pinto, especialmente entre 1945 e 1968, e apresenta um texto cujos capítulos estão divididos em três partes: 1) Álvaro Vieira Pinto - do Integralismo ao ISEB; 2) Do ISEB ao comício; 3) O intelectual entre a pré-revolução e o êxodo. Posteriormente, com a publicação póstuma de manuscritos até então inéditos, Marcos Cezar de Freitas (2005) propõe a noção de "quatro quadrantes", que formariam um círculo conceitual da obra de Álvaro Vieira Pinto, encaixando o que seriam suas quatro grandes obras: 1) Consciência e Realidade Nacional; 2) El Pensamento Crítico en Demografia; 3) Ciência e Existência e 4) O Conceito de Tecnologia.

Neste artigo optamos por uma exposição da produção intelectual do autor a partir de uma periodização em quatro seções: 1) Até os anos 1950: formação e posicionamento 
intelectual; 2) Início dos anos 1960: ISEB, ideologia e política; 3) Anos 1960 e anos 1970: ditadura e produção em exílio; e 4) Final dos anos 1970 e anos 1980: os manuscritos e as traduções. Entretanto, vemos com certa cautela a proposição de um grande esquema para estruturar sua obra, principalmente por não termos acesso a todos os seus escritos, como ficará claro ao longo deste artigo. Nossa proposta de quatro seções busca enfatizar o caráter de biobibliografia deste texto, realçando a publicação de conjuntos de obras a partir de determinados momentos históricos do pensamento e da vida de Álvaro Vieira Pinto, considerando que a produção do filósofo se desenvolveu a partir de conceitos recorrentes, mas que foram se transformando na sua própria plataforma conceitual, como Freitas (2005) já havia evidenciado, mas que vão além de sua proposta de quatro quadrantes. Ao contrário da periodização deste, temos como objetivo evidenciar outras publicações, não apenas os livros. Com a pesquisa e o recenseamento aqui delineado, levantamos que já nas primeiras obras de juventude, publicadas no final da década de 1920, Vieira Pinto organizou publicações (como os artigos de cunho religioso ou científico) de questões que perpassam sua carreira, importantes para a compreensão de seu desenvolvimento intelectual.

Assim, para favorecer uma visão cronológica da produção do autor, este artigo inclui duas seções principais, além desta seção introdutória (e sua subseção de metodologia) e da seção 4, de referências bibliográficas ao final. A seção 2 apresenta a trajetória biobibliográfica de Vieira Pinto, e a seção 3 lista a sua produção bibliográfica de modo diacrônico, organizado pela primeira edição ou disponibilização.

\section{A produção intelectual de Álvaro Vieira Pinto: biobibliografia}

Álvaro Borges Vieira Pinto nasceu em 1909 (Campos dos Goytacazes, RJ) e faleceu de infarto, em 1987 (Rio de Janeiro, RJ). Foi casado com Maria Aparecida Fernandes (Maria Aparecida Fernandes Vieira Pinto). Não tiveram filhos. Teve 2 irmãos e 1 irmã: Arnaldo Borges Vieira Pinto, Ernani Borges Vieira Pinto e Laura Vieira Pinto (casada Laura Vieira Pinto Ribeiro). Viveu e morou a maior parte de sua vida no Brasil. Estudou na França durante seu doutoramento (de 1949 a 1950) e neste período visitou Itália, Espanha e Portugal. Ministrou aulas no Paraguai (entre 1951-1952). No exílio, durante a ditadura brasileira, morou na Iugoslávia (de 1964 a 1965) e no Chile (de 1965 a 1968).

Foi Diretor Proprietário da revista católica "Pelo Brasil" (entre 1928-1929). Cursou Medicina de 1927 a 1932, tendo colação de grau em 3 de outubro de 1932. Atuou em Medicina por 1 ano (1932) como médico clínico (Aparecida, SP). Foi pesquisador na Fundação Gaffré e Guinle (Rio de Janeiro) por 16 anos (1933-1949). Ingressou no Curso de Física em 1937. Foi cronista na Revista Cultura Política (de 1941 a 1942), publicando artigos de divulgação científica. Trabalhou como professor na Faculdade de Filosofia do Distrito Federal (Rio de Janeiro) e na Faculdade Nacional de Filosofia (FNFi) da Universidade do Brasil, ministrando cursos de filosofia das ciências, lógica (formal/matemática) e história da filosofia. Tornou-se professor catedrático na Universidade do Brasil em 1950. Foi chefe do Departamento de Filosofia (de 1955 a 1961) do Instituto Superior de Estudos Brasileiros (ISEB), Rio de Janeiro, no qual também lecionava e ministrava cursos em filosofia. Em 1961 assume a diretoria executiva do ISEB, permanecendo até 1964, quando o instituto é fechado, quase que imediatamente após o golpe militar. Foge, é exonerado, processado e exilado, indo inicialmente para a Iugoslávia (1964-1965). No exílio, muda-se para o Chile (1965-1968), passando a atuar no Centro Latino-Americano de Demografia (CELADE), em ensino e pesquisa, e como tradutor. Ao retornar ao Brasil, em 1968, trabalha como tradutor, na maioria das vezes sob pseudônimo, devido às restrições impostas pe- 
lo regime militar de então. Continua escrevendo durante este período, sendo que alguns destes escritos são publicados postumamente.

O levantamento de obras de Álvaro Vieira Pinto até então realizado indica que a produção intelectual de Vieira Pinto inclui ao menos: 1 tese (1949); 9 livros publicados, sendo 7 publicados em vida $(1956,1960,1961,1962,1969,1973,1982)$ e 2 postumamente (2005 e 2008); 4 artigos científicos (1938, 1949, 1952 e 1963); 9 artigos de divulgação científica em coluna mensal em revista (1941-1942); 2 artigos em revista de cunho religioso (1929, 1930), 1 conto (1928), 1 apostila (1957); 1 introdução de livro (1958); 1 prefácio (1959) e 1 manual (1975) ${ }^{9}$. Sabe-se da existência de 4 manuscritos ainda não encontrados e não publicados, que o próprio autor menciona ${ }^{10} \mathrm{em}$ entrevista. Até o momento infere-se que 24 traduções suas foram publicadas, sendo $6 \mathrm{com}$ seu nome ${ }^{11}$ e supostamente $18 \mathrm{sob}$ pseudônimos.

\subsection{Até os anos 1950: formação e posicionamento intelectual}

Álvaro Borges Vieira Pinto nasceu em Campos dos Goytacazes (Rio de Janeiro), em 11 de novembro de 1909. ${ }^{12}$ Filho de Carlos Maya Vieira Pinto, e de Arminda Borges Vieira Pinto, família de descendência portuguesa, teve 1 irmã e 2 irmãos: Laura Vieira Pinto (Laura Vieira Pinto Ribeiro ${ }^{13}$ ), pianista; Ernani Borges Vieira Pinto, escrivão de justiça; e Arnaldo Borges Vieira Pinto, engenheiro civil. ${ }^{14}$

Após o exame de admissão, realizado no Colégio Pedro II $^{15}$, Vieira Pinto estudou (assim como seus irmãos) no Santo Inácio ${ }^{16}$, colégio jesuíta de ensino secundário do Rio de Janeiro ${ }^{17}$, onde realiza um curso de um ano de Filosofia de orientação tomista ${ }^{18}$. Após terminar seus estudos no Santo Inácio, havia decidido estudar Medicina, mas ainda era muito jovem para entrar na faculdade. Sua família muda para São Paulo ${ }^{19}$, onde fica um ano, e nesse tempo estuda literatura e filosofia ${ }^{20}$. Sem obrigações escolares, provavelmente em 1926, se relaciona "com alguns intelectuais que naquele tempo estavam saindo da agitação da Semana de Arte Moderna ${ }^{21}$, reunindo-se em cafés do Largo do Ouvidor ${ }^{22}$.

Ainda são poucas as informações sobre Vieira Pinto durante este período, especialmente de sua produção literária. Em fevereiro de 1928 publica na revista "Feira Literaria"23 o conto "O Homem que Creou um Mundo". Torna-se Diretor Proprietário ${ }^{24}$ da revista católica "Pelo Brasil" (1928-1929²5), revista para a qual também escreve ${ }^{26}$ textos, como "A Vara de Condão", de novembro de 1928. Também publica artigos na revista católica "A Ordem": o texto "Considerações sobre o milagre" em 1929 e "Jubileo de S.S. Pio XI" em $1930^{27}$, este último uma transcrição do discurso que Vieira Pinto proferiu na Associação dos Empregados do Commercio em homenagem ao papa.

Após sua passagem por São Paulo, retorna ao Rio de Janeiro e ingressa na Faculdade Nacional de Medicina ${ }^{28}$. Cursa o $1^{\circ}$ ano em 1927, o $2^{\circ}$ ano em 1928, o $4^{\circ}$ ano em 1931-2 e o $5^{\circ}$ ano em 1932, realizando colação de grau em 3 de outubro de $1932^{29}$. Como acadêmico de medicina, assume a vice-presidência da Ação Universitária Católica do Rio de Janeiro (AUC), em $1931^{30}$. Durante a faculdade, sua família passa por dificuldades: além de seu pai ter um fracasso econômico, sua mãe vem a falecer. Para ajudar a família, durante o $5^{\circ}$ e o $6^{\circ}$ anos de seu curso de Medicina, Vieira Pinto trabalha como professor, lecionando filosofia e física em um curso primário de um colégio de freiras. ${ }^{31}$ Os quatro irmãos recebem apoio de sua tia Cora, que auxilia no sustento e com o término de seus estudos. ${ }^{32}$

Após se formar, Álvaro Vieira Pinto busca atuar como médico e instala uma clínica em Aparecida (São Paulo). Seu consultório era em um quarto de hotel ${ }^{33}$ e as condições de trabalho eram precárias. Não obteve sucesso com a atividade e, sem apoio financeiro e ten- 
do que sustentar a família, retorna ao Rio de Janeiro. ${ }^{34}$ Em meados da década de 1930, por intermédio de um amigo, conhece o médico e pesquisador Álvaro Osório de Almeida, que realizava pesquisas sobre o câncer ${ }^{35}$ e os efeitos da radioterapia, e com ele começa a trabalhar na Fundação Gaffré e Guinle do Rio de Janeiro. ${ }^{36} \mathrm{O}$ laboratório de biologia funcionava em um hospital, realizando pesquisa e atendimento de enfermaria. ${ }^{37}$ Em maio de 1934, Vieira Pinto e Carlos Chagas Filho ofertam aulas de Biologia Experimental no Instituto Católico de Estudos Superiores ${ }^{38}$, ligado a Alceu Amoroso Lima. Em outubro de 1934, Álvaro ingressa na Ação Integralista Brasileira (AIB), interessado pela questão social a partir da temática da "identidade nacional". 39

Devido ao seu trabalho com pesquisa na mencionada Fundação, estava motivado em compreender problemáticas em torno dos raios-X, como a questão da física corpuscular, para entender sua aplicação no tratamento de pacientes e de animais. ${ }^{40}$ Com este objetivo, em 1937, Vieira Pinto começou a cursar, simultaneamente, Física e Matemática na Universidade do Distrito Federal (Rio de Janeiro), curso que encerrou no meio do ano, pois a escola fechou. Entretanto, segundo Álvaro, dos 16 anos que trabalhou no laboratório, os resultados de pesquisa foram nulos. ${ }^{41}$

Em agosto de 1938, publica seu primeiro artigo, na Revista do Brasil, denominado "Sciencias: a transmutação dos elementos". O breve texto trata da discussão científica sobre as possibilidades de transmutação dos elementos pela transformação atômica.

Enquanto ainda trabalhava no laboratório, Vieira Pinto começou a dar aulas de filosofia das ciências na Faculdade de Filosofia da Universidade do Distrito Federal (UDF), no Rio de Janeiro ${ }^{42}$. Em 1939 a UDF é extinta e seus cursos são transferidos para a recémcriada Universidade do Brasil (UB), na qual torna-se professor adjunto ${ }^{43}$. Começa a ministrar aulas de lógica na Faculdade Nacional de Filosofia (FNFi) da $\mathrm{UB}^{44}$ e, um ano depois, em torno de 1941, como professor substituto, começa a ministrar o curso de "História da Filosofia" da FNFi pois, com a II Guerra Mundial, houve uma mudança dos professores alemães, e Vieira Pinto era o único assistente na cadeira de Filosofia ${ }^{45}$.

Entre 1941 e 1942, Vieira Pinto escreve uma coluna mensal na Revista Cultura Política. Foram ao todo 9 artigos de divulgação científica no formato de breves relatos sobre a pesquisa científica no Brasil. ${ }^{46}$ A coluna apresentava, a cada mês, relatos sobre a pesquisa recente daquela época, tratando de diferentes temáticas e com uma abordagem otimista. Os breves textos de divulgação científica abordam o trabalho de pesquisadores como Carlos Chagas, J. Costa Ribeiro, Lélio Gama, Miguel Osório de Almeida, F. M. de Oliveira Castro e Mario Schönberg.

O ano de 1949 marca um momento importante da produção filosófica de Vieira Pinto. Neste ano, no número inaugural da Revista da Faculdade Nacional de Filosofia, tem publicado o seu artigo "Considerações sobre a lógica do antigo estoicismo" ${ }^{47}$. Nele, discute o estoicismo na história da filosofia e sua relação com a origem dos fundamentos da lógica moderna. Também em 1949, Vieira Pinto vai à Europa estudar na Sorbonne, em Paris, na França. ${ }^{48}$ Ficou quase um ano ${ }^{49}$ estudando e elabora o tema de sua tese, para defesa de cátedra. Em Paris, ministrou duas conferências sobre a tese e recolheu material ${ }^{50}$ para sua tese sobre a Cosmologia de Platão, que foi discutida e aprovada por vários helenistas consagrados. ${ }^{51}$ No prefácio da tese, Vieira Pinto agradece Émile Bréhier (que havia sido professor da Universidade do Distrito Federal) pelo convívio e debates tidos em torno do seu texto, assim como Pierre Maxime Schuhl pelo convite que lhe foi feito para ocupar a cátedra de Filosofia Grega da Sorbonne ${ }^{52}$ e também pelas contribuições à discussão das questões da tese. ${ }^{53}$ Vieira Pinto também havia convivido com René Poirier (que tinha sido responsável pela cadeira de "História da Filosofia" na FNFi) com quem discutiu ideias de 
sua tese. ${ }^{54}$ Em sua viagem pela Europa, também visitou Itália, Espanha e Portugal, mas sem fins de estudo nestes países. ${ }^{55}$

Em maio de 1949 conclui sua tese, Ensaio sobre a Dinâmica na Cosmologia de Platão, apresentada e defendida em $1950^{56}$ na Faculdade Nacional de Filosofia (FNFi), no Brasil, ${ }^{57}$ que a aprova e lhe dá o título de professor catedrático ${ }^{58}$. A tese de livre-docência, dedicada a San Thiago Dantas (1911-1964), advogado, professor e político, e a Plínio Rocha (1911-1972), físico e professor, foi apresentada a uma banca composta pelos professores Nilton Campos, Leandro Ratsibona, Lívio Teixeira, José Barreto Leite e frei Damião Berge. ${ }^{59}$ A extensa tese aborda uma questão de tradução a respeito da passagem $43 \mathrm{~b}$ do Timeu (um dos diálogos de Platão), e propõe uma tradução mais adequada ${ }^{60}$ ao trecho original $^{61}$. Segundo Maria Moraes Augusto, a principal hipótese da tese é "que na concepção de phýsis, exposta no Timeu e nas Leis já está contido o princípio da inércia, incluído na estrutura de seu 'sistema de Natureza'." (MORAES AUGUSTO, 2009/10, p.115, grifos da autora)

Após prestar concurso, com a aprovação de sua tese, reassumiu a cadeira de "História da Filosofia". ${ }^{62}$ De professor adjunto passou a professor titular, sendo nomeado professor catedrático na $\mathrm{FNFi}^{63}$, substituindo o professor René Poirier - que havia retornado à França $^{64}$. Em entrevista a Fáveri $(2014$, p.96) ex-alunos comentam a clareza e profundidade das aulas de Vieira Pinto na época, que ministrava as aulas sozinho, e que, mais tarde, teve como assistente um ex-aluno, José Américo Pessanha. ${ }^{65}$ Logo depois encerrou seu trabalho no laboratório de Biologia, pois o laboratório foi privatizado, decisão com a qual Vieira Pinto não concordava. ${ }^{66}$

Em março de 1951 publica na revista do Diretório Acadêmico da Faculdade Nacional de Filosofia da Universidade do Brasil, sua tradução do "Perì Phýseos", o poema de Parmênides. ${ }^{67}$ A partir de sua tese, elabora um pequeno trabalho, publicado em 1952 na revista acadêmica francesa Revue des Études Grecques (v.65, n.65), chamado "Note sur la traduction de Platon, Timée 43 b", que consiste em um comentário sobre o passo 43b do Timeu de Platão ${ }^{68}$ em relação a Timeu $31 \mathrm{a}$, buscando mostrar que na visão cosmológica de Platão já está expressa uma noção do princípio da inércia. ${ }^{69}$

Ainda em 1951, em 6 de setembro, o Presidente da República assina decreto autorizando o professor Álvaro Borges Vieira Pinto a integrar a Missão Cultural Brasileira em Assunção, Paraguai ${ }^{70}$ (e em 31 de agosto do mesmo ano, recebe pagamento de gratificação relacionado à Missão Cultural ${ }^{71}$ ). Em 1952, recebe o título de Doutor Honoris Causa da Universidade Nacional do Paraguai ${ }^{72}$. Sobre as atividades desenvolvidas na Faculdade de Filosofia de Assunção, Vieira Pinto posteriormente escreve um relatório (Ofício n. ${ }^{\circ}$ 299, de 12 nov. 1954, da Embaixada Brasileira, documento elaborado para a Secretaria do Estado das Relações Exteriores), defendendo a continuidade da Missão Cultural Brasileira no Paraguai. ${ }^{73}$ Em 1957 será publicada a transcrição de suas aulas no Paraguai, reunidas pelo escritor José Maria Rivarola Matto, na apostila "Filosofía Actual", escrita em espanhol. ${ }^{74}$ Revista e aprovada por Vieira Pinto em maio de 1956, a apostila apresenta as bases de discussão sobre o pensamento filosófico contemporâneo, especialmente da fenomenologia e do existencialismo a partir de autores como Søren Kierkegaard, Martín Heidegger, JeanPaul Sartre e Karl Jaspers. ${ }^{75}$

Em 1954 foi concedido à Vieira Pinto, pelo Presidente da República, uma autorização para assumir por dois anos a direção do Instituto de Cultura Boliviano-Brasileiro, e organizar e dirigir a cadeira de Estudos Brasileiros na Universidade de San Andrés, em La Paz, Bolívia. ${ }^{76}$

Nestes primeiros momentos, que abordamos nesta seção inicial do artigo, com sua formação inicial no Colégio Santo Inácio, sua relação com o catolicismo e a aproximação 
ao movimento integralista, Álvaro Vieira Pinto forma uma rede de contatos que lhe vai oferecer oportunidades, como, por exemplo, a vice-presidência da Ação Universitária Católica (AUC) do Rio de Janeiro e os convites para ingressar como professor universitário ${ }^{77}$. De médico e cientista a professor de filosofia, Vieira Pinto realiza atuações próximas ao âmbito governamental, como sua participação na revista Cultura Política e na Missão Cultural no Paraguai. Quanto ao integralismo, segundo Marcos Cezar de Freitas (1998, p.34) é interessante observar que o nacionalismo do autor se modifica, das origens próximas ao integralismo às posições que assume no ISEB. Deste momento na sua vida e obra, para o seguinte, muda seu posicionamento quanto à questão popular, formando sua crítica ao autoritarismo e trazendo sua preocupação com a questão do desenvolvimento do terceiro mundo.

\subsection{Início dos anos 1960: ISEB, ideologia e política}

O Instituto Superior de Estudos Brasileiros (ISEB) é criado em 1955. Álvaro Vieira Pinto já integrava o conselho consultivo do instituto, e recebe o convite para assumir o Departamento de Filosofia. ${ }^{78}$ No ISEB, vai atuar como professor de filosofia, ministrando cursos, realizando traduções e escrevendo livros. Segundo o próprio autor, começa a mudar a orientação com que desenvolvia suas aulas, apresentando uma visão mais crítica. ${ }^{79}$ Desde a criação do Instituto, trabalhavam nos serviços de secretaria do Instituto as irmãs Maria Aparecida Fernandes e Lourdes, sendo Maria a primeira funcionária. Ao longo de seu trabalho no ISEB, Maria Aparecida mantinha contato com Vieira Pinto, realizando trabalhos de datilografia de manuscritos. ${ }^{80}$

No auditório do Ministério da Educação e Cultura (MEC), em 14 de maio de 1956, Vieira Pinto realiza a aula inaugural do curso regular do ISEB, que contou com a presença do então presidente Juscelino Kubitschek. ${ }^{81}$ A transcrição desta aula foi publicada pelo ISEB ainda em 1956, no livro "Ideologia e Desenvolvimento Nacional". O livro vem a ser republicado em 1960, com pequena modificação no texto, conforme o próprio autor informa na introdução do livro. Posteriormente, em 1969, o livro recebe uma tradução para o espanhol.

Em 1958, é publicado "Razão e anti-razão em nosso tempo" de Karl Jaspers, o primeiro livro da coleção "Textos de Filosofia Contemporânea", que o ISEB se propôs a editar. O livro é traduzido por Vieira Pinto, que também escreve a Introdução de "Razão e anti-razão em nosso tempo", na qual defende a importância da tradução de obras contemporâneas. Apesar da publicação das traduções não ter recebido continuidade ${ }^{82}$, a coleção tinha como proposta vir a publicar obras de pensadores das principais correntes filosóficas do período, especialmente na filosofia da existência, do marxismo e da filosofia analítica, como Gabriel Marcel, Jean-Paul Sartre, Alfred Jules Ayer, Ortega y Gasset, Lefêvre ${ }^{83}$ e Lukács. ${ }^{84}$ Em 1959, Vieira Pinto recebe o convite de Michel Debrun para escrever o prefácio de "Ideologia e Realidade", obra que é publicada pelo ISEB naquele mesmo ano. ${ }^{85}$ Ainda neste mesmo ano, assina o "Manifesto dos Educadores: mais uma vez convocados".

Durante a visita de Jean-Paul Sartre ao Brasil, em 1960, quando este esteve no Rio de Janeiro, ocorre o encontro entre os dois filósofos, descrito por José Mauro no jornal Última Hora:

"Ontem, pela manhã, conversaram no bar do Hotel Miramar, em Copacabana, com o filósofo Jean-Paul Sartre, os Professores Rolan Corbisier, Álvaro Vieira Pinto e Cândido Mendes de Almeida. A conversa, que durou mais de três horas, versou sobre nacionalismo e colonialismo." (MAURO, 1960) 
Em setembro de 1960, Álvaro Vieira Pinto publica pelo ISEB o primeiro volume de sua primeira grande obra, "Consciência e Realidade Nacional", com o segundo tomo sendo publicado em junho do ano seguinte. ${ }^{86}$ Inicialmente preparada para receber o nome de "Gênero e Formas da Consciência Nacional" ${ }^{87}$, a obra integrou a coleção "Textos Brasileiros de Filosofia", do ISEB, sendo o primeiro desta coleção. Por indicação do ministro da educação $^{88}$, em $1961^{89}$ Vieira Pinto assume como diretor executivo do ISEB, deixando a direção do Departamento de Filosofia. ${ }^{90}$ Porém, "[a]o assumir o Instituto, Vieira enfrentou graves problemas financeiros somados a uma feroz campanha difamatória incessantemente movida por grupos de direita e pela imprensa." (CÔRTES, 2003, p.320)

O início da década de 1960 foi um período de publicações engajadas para Vieira Pinto. A partir do pedido da diretoria da UNE (União Nacional dos Estudantes) para publicar uma conferência que ministrou em 1961, em Belo Horizonte ${ }^{91}$, o livro "A questão da Universidade" é lançado no mesmo ano pela Editora Universitária ${ }^{92}$, formada por lideranças estudantis ligadas à União Metropolitana e à UNE. ${ }^{93}$ Segundo Michelle Lima (2015, p.108), o livro "representa a mobilização em torno do processo da reforma universitária, motivada pelas contradições no interior das instituições, mas também pelas condições sociais da época." No ano seguinte, Ênio Silveira e Vieira Pinto coordenam a coleção "Cadernos do Povo Brasileiro" da Editora Civilização Brasileira. Os cadernos tinham formato de bolso e tiragem mínima de 15 mil exemplares. ${ }^{94}$ Foram editados no período de 1962 a 1964, formando um total 24 livros (mais volumes extras), cuja publicação foi interrompida pela ditadura militar. ${ }^{95}$ Vieira Pinto escreve o livro número 4 desta coleção, publicado em 1962 com nome "Por que os ricos não fazem greve?". Este livro também viria a ser publicado em Portugal, em 1975.

Em 1962, com o intenso debate em torno do plebiscito que colocava em questão o sistema parlamentarista então vigente, o ministro da educação Darcy Ribeiro requisita ao ISEB a confecção de um documento em defesa do retorno do presidencialismo. ${ }^{96} \mathrm{O}$ folheto "Por que votar contra o parlamentarismo no plebiscito?" foi redigido por Osny Duarte Pereira (embora não conste na publicação), assinado por Álvaro Vieira Pinto pela Congregação de professores e alunos do do ISEB. ${ }^{97}$ Após ser publicado e amplamente distribuído (foi divulgado no jornal $\mathrm{O}$ Semanário, por exemplo ${ }^{98}$ ), gerou protestos de setores conservadores no Congresso e de jornais como O Globo. Houve inclusive uma tentativa de apreensão do panfleto, com a invasão da Gráfica Lux, onde foi impresso. ${ }^{99}$

Em julho de 1963, é publicado na Revista Brasileira de Estudos Sociais do Departamento de Ciências Econômicas da Universidade de Minas Gerais o artigo "Indicações metodológicas para a definição de subdesenvolvimento" ${ }^{100}$, texto em que Vieira Pinto busca responder às críticas que recebeu sobre seu conceito de "subdesenvolvimento"101. No mesmo ano, em 7 de outubro, é criado o Comando dos Trabalhadores Intelectuais (CTI), o qual Vieira participa na comissão diretora ${ }^{102}$ e em 24 de janeiro de 1964 integra o Conselho Deliberativo. ${ }^{103}$

O começo dos anos 1960, além de ser exemplar para a produção bibliográfica de Vieira Pinto, também é um período de revisão do seu posicionamento político e intelectual. É durante a atuação no ISEB que Vieira Pinto rompe com princípios católicos e integralistas, se posiciona politicamente à esquerda ${ }^{104}$ e desenvolve sua leitura terceiro-mundista da realidade brasileira, do existencialismo e do marxismo. ${ }^{105}$ Sua atuação como diretor do ISEB acontece em um período de turbulência, pois o Instituto foi alvo de uma campanha difamatória pelos meios de comunicação ${ }^{106}$ (notadamente, atacado pelo O Globo, porém defendido na imprensa carioca pelos jornais Última Hora e Diário de Notícias ${ }^{107}$ ), teve a verba cortada ${ }^{108}$ e contou com o apoio de apenas alguns poucos colegas ${ }^{109}$. Entretanto, foi 
um momento de grande engajamento político de Vieira Pinto, de contato direto com grandes questões nacionais, assim como foi no ISEB que conhece Maria Aparecida Fernandes, com quem viria a se casar e viver até falecer.

\title{
2.3. Anos 1960 e anos 1970: ditadura e produção em exílio
}

Em 1964 o Brasil sofre o golpe militar. O ISEB é invadido e tem seu acervo, sua biblioteca e seus móveis inutilizados, espalhados pelos jardins da sua sede. ${ }^{110} \mathrm{O}$ governo decreta a extinção do ISEB, em 13 de abril de 1964, e é instaurado um Inquérito Policial Militar (IPM). ${ }^{111}$ Vieira Pinto, então diretor do ISEB, é perseguido para ser preso e julgado. Ênio Silveira relata o momento em que souberam do golpe:

\begin{abstract}
"Nelson Werneck Sodré, Alex Vianni, Álvaro Vieira Pinto e eu descemos os trinta andares da Rádio Nacional pela escada de serviço, correndo. O golpe já estava dado, a UNE estava sendo incendiada, o jornal Última Hora tinha sido invadido e empastelado. Dirigi-me para a embaixada da Iugoslávia, cujo embaixador era um querido amigo. Chegamos na embaixada e a encontramos fechada (...) Assim que abriu entramos e ocupamos a embaixada como um asilo provisório. $\mathrm{O}$ embaixador chegou depois e confirmou que a situação estava mesmo ruim. Pedi para ficarmos lá por um tempo, umas horas, até que se definisse a situação. Ficamos vinte e quatro horas na embaixada da Iugoslávia, sem formalizar pedido de asilo; depois cada um foi para o seu destino." (ÊNIO SILVEIRA apud CÔRTES, 2003, p.321)
\end{abstract}

Em virtude da perseguição militar e buscando apoio legal para se sentirem mais seguros com a ida para o exílio, Álvaro Vieira Pinto e Maria Aparecida Fernandes se casam em 12 de junho de $1964^{112}$. Os dois se refugiam no interior de Minas Gerais, e Vieira Pinto assume o pseudônimo de Francisco Guimarães. ${ }^{113}$ Com ajuda de Ênio Silveira, pede asilo à Iugoslávia, e com apoio de seu irmão Arnaldo, escapa do cerco policial e parte para o exílio, em setembro de $1964 .{ }^{114} \mathrm{Na}$ Iugoslávia, com $55 \operatorname{anos}^{115}$, Vieira passa um ano inativo, pois não conhecia a língua ${ }^{116}$. Acaba aprendendo um pouco de sérvio-croata, para poder ler os jornais e ter notícias do Brasil. ${ }^{117}$ Neste período, inicia o manuscrito de um dos livros que ainda continua desaparecido e sem publicação, sobre a crítica da existência. ${ }^{118}$

Em 1965, Paulo Freire sugere que Vieira Pinto mude para Santiago do Chile, e recebe convite para realizar conferências com professores do Ministério da Educação, junto com o próprio Paulo Freire. ${ }^{119}$ Durante o ano de 1966, Vieira Pinto ministra conferências sobre educação e, depois, cursos extras de verão, para professores. ${ }^{120}$ No final de 1966 , publica pequenos artigos em revistas universitárias chilenas ${ }^{121}$ e de outubro a dezembro de 1967 oferece curso de extensão sobre "Filosofia de las Ciências" a uma turma de médicos sanitaristas, na Escuela de Salubridad da Universidade do Chile ${ }^{122}$.

Por intermédio de um amigo, foi apresentado à diretoria do Centro LatinoAmericano de Demografia (CELADE), que requisitou inicialmente de Vieira Pinto a tradução de pequenos panfletos e, depois, foi contratado para escrever um livro sobre demografia. ${ }^{123}$ Mesmo sem conhecer a área, inicia seus estudos e pesquisas para escrever, em espanhol, o livro "El Pensamiento Crítico en Demografia", finalizado em oito meses (por volta de 1968), mas que foi editado pelo CELADE apenas em $1973^{124}$, tendo ampla repercussão $^{125}$. Desse livro, resulta também o manual "La Demografía como Ciencia", publi- 
cado em 1975, resumindo as principais questões do livro em 30 páginas, incluindo um glossário.

Quase simultaneamente à escrita da obra sobre demografia, o filósofo recebe contrato para outro livro. O texto, inicialmente intitulado "O método científico", viria a se chamar "Ciência e Existência". Este livro é elaborado a partir de suas aulas ministradas no Chile $^{126}$, mas o CELADE não teve interesse em publicá-lo. Foi publicado no Brasil, em português, em 1969, Segundo texto de dedicatória do livro: "O presente trabalho foi escrito em Santiago do Chile durante o ano de 1967 no cumprimento de um contrato concedido ao Autor pelo Centro Latino-Americano de Demografia. Nele estão contidos alguns dos principais conceitos das aulas ministradas pelo autor aos alunos do Curso Avançado daquele órgão das Nações Unidas." (VIEIRA PINTO, 1969, prefácio)

Durante sua passagem pela Iugoslávia e pelo Chile, Vieira Pinto havia se retraído e isolado. Isso muda com os convites que recebe para a elaboração de livros ${ }^{127}$, mas sentia cada vez mais saudades de sua terra natal ${ }^{128}$. Após três anos no Chile e quatro em exílio, retorna ao Brasil ao final de $1968^{129}$.

Durante o exílio e após o retorno ao Brasil, Vieira Pinto continua a escrever. Porém, impedido de publicar no Brasil, alguns textos foram editados apenas postumamente. Outras obras são publicadas após alguns anos. Livros como "Sete Lições sobre Educação de Adultos" e "Ciência e Existência" derivam das aulas que ministrou no Chile, mas só foram publicadas após seu retorno ao Brasil. Outro caso é de "El Pensamiento Crítico en Demografia" que, apesar de finalizado em 1968, foi publicado pelo CELADE apenas em 1973.

\subsection{Final dos anos 1970 e anos 1980: os manuscritos e as traduções}

A perseguição política e a experiência do exílio marcaram profundamente Vieira Pinto, que tinha muitas saudades do Brasil. ${ }^{130}$ Por intermédio de um advogado amigo da família, consegue negociar com os militares o seu retorno. ${ }^{131}$ Em dezembro de 1968, Álvaro Vieira Pinto e Maria Aparecida Fernandes Vieira Pinto voltam ao Brasil, na véspera do decreto do Ato Institucional n. ${ }^{\circ} 5$ (AI-5). ${ }^{132}$ A condição para seu retorno foi a proibição de ministrar aulas em universidades e de realizar conferências. ${ }^{133}$ Nesta situação, Vieira Pinto é levado por um medo profundo, e recolhe-se em seu apartamento em Copacabana, no Rio de Janeiro, com sua esposa Maria Aparecida. ${ }^{134}$

Fluente em muitas línguas ${ }^{135}$, o primeiro trabalho que Vieira Pinto consegue é pela Editora Vozes, editora católica da cidade de Petrópolis, assumindo o trabalho de tradutor ${ }^{136}$ para garantir o seu sustento. Sob diversos pseudônimos, como Francisco M. Guimarães, Mariano Ferreira e Floriano de Souza Fernandes ${ }^{137}$, Vieira Pinto traduziu diversas obras. ${ }^{138}$ Com base nas informações do levantamento feito por Norma Côrtes (2003), com base nestes pseudônimos, identificamos 24 traduções potencialmente realizadas por Vieira Pinto ao longo de sua vida ( 6 traduções realizadas com seu nome e 18 sob pseudônimos ${ }^{139}$ ), sendo 22 as traduções datadas deste momento de sua vida.

Em 1969 a obra "Ciência e Existência" é publicada no Brasil pela editora Paz e Terra (Rio de Janeiro), e seu livro "Ideologia e Desenvolvimento Nacional" é lançado em uma edição em espanhol, como "Ideología y desarrollo nacional", pelo "Centro Interamericano de Desarrollo Rural y Reforma Agraria", de Bogotá, na Colômbia.

Apesar disso, no período de 1970 a 1978, Vieira Pinto permanece em seu apartamento ${ }^{140}$, trabalhando como tradutor. Entretanto, em meio à ditadura militar, nem este trabalho lhe oferecia alguma tranquilidade. Ênio Silveira, com quem editou os Cadernos do Povo Brasileiro, editor da Civilização Brasileira, relata que ao ver seu amigo afastado de 
suas funções, ofereceu-lhe o trabalho de traduzir diretamente do russo as obras escolhidas de Lenin. Ênio comenta que este projeto foi uma forma que encontrou para ajudar Vieira Pinto, lhe oferecendo uma comissão mensal para traduzir três volumes de mil páginas cada. Apesar de não esperar que o trabalho fosse concluído, Vieira Pinto traduziu dois volumes que Ênio enviou para impressão. Apesar de estarem em meio a uma ditadura com um discurso "anti-comunista", o editor acredita na relevância histórica e intelectual de Lenin, assim como já havia publicado outros importantes autores, como Marx e Engels. Entretanto, a gráfica foi invadida, os originais dos dois livros apreendidos, e materiais da gráfica foram levados, como filmes e fotolitos. Também foram levados os cinco mil exemplares impressos do livro (cada um com cerca de mil páginas), o que resultou na descontinuidade do projeto em virtude dos custos para reparar a gráfica e o prejuízo do investimento. ${ }^{141}$

Em 1973 o CELADE publica "El pensamiento crítico en Demografia", que havia escrito ainda no Chile.

Como já mencionado, Vieira Pinto continua a escrever, mas vê-se impedido de publicar. Em 5 de abril de 1973 termina a terceira e última revisão de "O Conceito de Tecnologia", que é datilografado em uma primeira via em 19 de fevereiro de $1974^{142}$ e que viria a ser publicada em 2005, postumamente. Em 27 de janeiro de 1975, termina uma primeira versão de seu texto, na forma de manuscrito, de "Sociologia do vale de lágrimas", considerado pelo próprio autor como um rascunho de um futuro livro que não esperava publicar. Esta obra vem a ser publicada em 2008 com o título de "A Sociologia dos Países Subdesenvolvidos". Também em 1975 o livro "Porque os ricos não fazem greve" é publicado em Portugal, pela Editora DiAbril, com o nome "Os ricos não fazem greve - porquê?".

No ano de 1977, Álvaro Vieira Pinto recebe a visita de Demerval Saviani e três professoras da Universidade Federal de São Carlos (UFSCar), que observam seu trabalho anônimo e sistemático. ${ }^{143}$ Demerval retorna em 1981 à casa de Vieira Pinto, para colher um depoimento para a Revista da Associação Nacional de Educação (ANDE). Encontra Vieira Pinto em más condições de saúde e muito cansado, e a entrevista acaba incompleta. ${ }^{144}$ Nessa época, com a anistia, Vieira Pinto e Maria Aparecida Fernandes haviam regularizado sua situação no Brasil $^{145}$ e o autor estava aposentado pela Universidade Federal do Rio de Janeiro (UFRJ), que havia absorvido a Faculdade Nacional de Filosofia (FNFi) na qual Vieira Pinto era concursado ${ }^{146}$.

Em virtude de debates no curso de doutorado, um projeto de pesquisa sobre alfabetização de adultos é desenvolvido pela USFCar entre o período de agosto de 1982 e julho de 1983. Coordenado por Demerval Saviani e Betty Antunes de Oliveira, durante este projeto os professores entraram em contato Vieira Pinto e realizaram entrevistas, e com isso tiveram acesso às anotações de Vieira Pinto sobre a alfabetização de adultos, e o convencem a publicá-las, dando origem ao livro "Sete lições sobre Educação de Adultos", publicado pela Editora Cortez (São Paulo) em 1982. ${ }^{147}$ Em 1986, o livro "A questão da Universidade" é reeditado também pela Editora Cortez e Autores Associados.

Aos setenta e oito anos, em 11 de julho de 1987, morre de infarto Álvaro Vieira Pinto, na Casa de Saúde Santa Maria, Rio de Janeiro. ${ }^{148}$ No final de sua vida, além das traduções, Vieira Pinto desenvolve uma vasta produção. Em sua penúltima entrevista, cedida a Demerval Saviani em julho de $1981^{149}$, o autor comenta sobre manuscritos ainda não publicados na época:

"E agora fico só com o que tenho guardado para publicar, mas é muita coisa! Tenho um livro sobre Tecnologia, que é muito grande, vários volumes para abranger a matéria toda. Tenho pronto um livro sobre a Filosofia Primeira; outro com o título A educação para um país oprimido. Tenho outro sobre os roteiros do curso de Educação de Adultos feito no 
Chile. Considerações éticas para um povo oprimido, livro sobre a ética que considero de grande valor no meu pensamento, porque não se dá à ética a importância que ela tem e centralizo um grande número de questões em torno de problemas éticos. Daí desenvolvi um livro que trata exatamente da ética, mas da ética concreta, da ética real, de um País como o nosso, não é ética abstrata dos valores, das teorias, ou noções abstratas do dever, obediência, finalidade, nada disso. A ética real que funciona no mundo. A sociologia do povo subdesenvolvido é outro livro que tenho pronto. Cada livro tem 3 e 4 volumes. A crítica da existência é outro livro que está guardado, um volume só, incompleto, pois não pude continuar escrevendo o que desejada porque estava cansado." (VIEIRA PINTO, 1984. p.20, grifos nossos)

Destas obras citadas pelo próprio Álvaro Vieira Pinto na entrevista de 1981, três foram publicadas: "livro sobre Tecnologia (...) vários volumes" (publicado como "O Conceito de Tecnologia"); A sociologia do povo subdesenvolvido (publicado como "A Sociologia dos países subdesenvolvidos"); "roteiros do curso de Educação de Adultos feito no Chile" (publicado como "Sete lições sobre Educação de Adultos")

O texto da obra "O Conceito de Tecnologia" foi editado em 2005 pela Editora Contraponto (Rio de Janeiro), com quatro volumes publicado em dois livros. Com o falecimento de Vieira Pinto e de sua esposa, o advogado Perílio Guimarães Ferreira, amigo da família, passou a gerir os bens, entre os quais estava "O Conceito de Tecnologia". Após a morte de Perílio, o livro foi encontrado pela sua irmã, Orsely Guimarães Ferreira de Brito, exaluna de Vieira Pinto. O reconhecimento do livro como obra de Álvaro Vieira Pinto foi feito por sua amiga, Marília Barroso, também ex-aluna, que entraram em contato com a professora Maria da Conceição Tavares e fizeram contato com a editora. ${ }^{150}$

Logo após, em 2008, além da primeira reimpressão de "O Conceito de Tecnologia" é publicada a obra "A Sociologia dos Países Subdesenvolvidos", manuscrito inédito editado pelo professor José Ernesto de Fáveri. Mariza Urban, sobrinha de Álvaro Vieira Pinto, guardava o manuscrito ainda não concluído desde o falecimento de seu pai, o irmão mais novo de Vieira Pinto. ${ }^{151}$

Das obras citadas anteriormente, portanto, ainda não foram encontradas: "livro sobre a Filosofia Primeira" (não publicado, localização desconhecida); A educação para um país oprimido (não publicado, localização desconhecida); Considerações éticas para um povo oprimido (não publicado, localização desconhecida); A crítica da existência (incompleto, não publicado, localização desconhecida).

Também é importante lembrar que, mesmo entre as obras já publicadas, a maior parte da bibliografia de Vieira Pinto se encontra esgotada e sem reedições, ou ainda está publicada apenas em espanhol, sem ter sido publicada em português.

\section{Considerações finais}

Com este levantamento, esperamos ter elaborado um recurso que possa servir de introdução ao referencial biobibliográfico sobre Álvaro Vieira Pinto e como ferramenta para novas investigações. Além da atualização de informações, acreditamos que a recuperação de referências de vida e de textos do filósofo (especialmente de sua juventude), que ainda não eram consideradas pela literatura conhecida sobre o autor, podem servir de apoio para releituras sobre sua vida e obra. 
No Programa de Pós-Graduação em Tecnologia e Sociedade (PPGTE) da Universidade Tecnológica Federal do Paraná (UTFPR) de Curitiba, temos realizado outras pesquisas que visam facilitar uma visão mais panorâmica da obra de Vieira Pinto, mas ao mesmo tempo com informações precisas e completas. Almejamos produzir outros recursos, como uma bibliografia comentada, que, por sua vez, tem por objetivo contribuir para a estruturação, organização e disponibilização de uma coleção de referências, digital e aberta, dedicada a este pensador, a ser disponibilizada no repositório de acesso aberto Ar$\mathbf{c a z}^{152}$ de modo experimental, e quando consolidada, futuramente em Coleção Especial no Repositório e Outras Coleções Abertas (RoCA). No repositório Arcaz já estão disponíveis, por exemplo, o início de uma coleção de Recursos Educacionais Abertos (REA) sobre Álvaro Vieira Pinto, produzidos em pesquisa de iniciação científica na Pontifícia Universidade Católica do Paraná (PUCPR). Também estão em desenvolvimento uma coleção aberta de referências ${ }^{153}$, iniciada em 2014 , com a disponibilização de um material aberto e acessível em plataforma de auxílio à administração de referências bibliográficas, a Zotero, de modo a concentrar e organizar uma ampla quantidade de informações em um único local, sobre um levantamento da produção bibliográfica acadêmica deste autor e da produção de terceiros, e o sítio eletrônico "Centro de Estudos sobre Álvaro Vieira Pinto" ${ }^{154}$, projeto desenvolvido desde 2015, oferecendo para acesso compilações de referências, em ordem cronológica, sobre a biografia e bibliografia do autor brasileiro, e reunião de recursos abertos para consulta e pesquisa sobre o filósofo.

Estes esforços de sistematização do legado intelectual de Álvaro Vieira Pinto são apenas o começo de uma pesquisa de longo prazo, mas que já nos nos permitem compreender melhor não apenas a trajetória das ideias deste pensador, mas também os contornos e caminhos de uma pequena parte da história do Brasil e da América Latina, em parte não reconhecida, como muitas outras.

\section{Bibliografia de Álvaro Vieira Pinto}

Apresentamos nesta seção uma lista da produção bibliográfica de Vieira Pinto com o intuito de facilitar a consulta de demais pesquisadores e pesquisadoras. As referências abaixo são resultado da pesquisa para a coleção aberta de referências, disponível desde 2014, na plataforma Zotero ${ }^{155}$ como projeto colaborativo, e em 2015 no sítio eletrônico "Centro de Estudos sobre Álvaro Vieira Pinto", onde informações mais detalhadas sobre cada obra podem ser encontradas.

Obras de sua autoria, em ordem cronológica de primeira publicação:

- VIEIRA PINTO, Álvaro. O Homem que Creou um Mundo. In: Feira Literaria, v. II, São Paulo: Empreza de Divulgação Literária, fev. 1928. p.101-117.

- VIEIRA PINTO, Álvaro. A Vara de Condão. In. Pelo Brasil, ano I, n.3. Rio de Janeiro, 10 nov. 1928. p.47-50.

- VIEIRA PINTO, Álvaro. Considerações sobre o milagre: A objecção da conservação da energia. In: A Ordem, ano VIII, vol. I, n.1 (especial) e n.2 (nova série). Rio de Janeiro: Typ. do Annuario do Brasil, 1929. p.20-29.

- VIEIRA PINTO, Álvaro. Jubileo de S.S. Pio XI. In: A Ordem, ano X, vol. II, n.5 (nova série). Rio de Janeiro: Typ. São Benedicto, fev. 1930. p.63-66.

- VIEIRA PINTO, Álvaro. Sciencias: a transmutação dos elementos. In: Revista do Brasil, ago. 1938. p.198-201. 
- VIEIRA PINTO, Álvaro. Estudos e Pesquisas Científicas I. In: Cultura Política Revista Mensal de Estudos Brasileiros, n. I, 1941. p.264-273.

- VIEIRA PINTO, Álvaro. Estudos e Pesquisas Científicas II. In: Cultura Política Revista Mensal de Estudos Brasileiros, n. II, 1941 p.270-272.

- VIEIRA PINTO, Álvaro. Estudos e Pesquisas Científicas III: A radioatividade de alguns minerais brasileiros. In: Cultura Política - Revista Mensal de Estudos Brasileiros, n. III, 1941. p.278-280.

- VIEIRA PINTO, Álvaro. Estudos e Pesquisas Científicas IV. In: Cultura Política - Revista Mensal de Estudos Brasileiros, n. V, 1941. p.286-288.

- VIEIRA PINTO, Álvaro. Estudos e Pesquisas Científicas V. Contribuições Brasileiras à Matemática. In: Cultura Política - Revista Mensal de Estudos Brasileiros, n. VI, 1941. p.292-294.

- VIEIRA PINTO, Álvaro. Estudos e Pesquisas Científicas VI. In: Cultura Política - Revista Mensal de Estudos Brasileiros, n. VII, 1941. p.309-311.

- VIEIRA PINTO, Álvaro. Estudos e Pesquisas Científicas VII. Contribuições Brasileiras à Matemática. In: Cultura Política - Revista Mensal de Estudos Brasileiros, n. VIII, 1941. p.284-286.

- VIEIRA PINTO, Álvaro. Estudos e Pesquisas Científicas VIII. Contribuições Brasileiras à Matemática. In: Cultura Política - Revista Mensal de Estudos Brasileiros, n. XII, 1942. p.256-258.

- VIEIRA PINTO, Álvaro. Estudos e Pesquisas Científicas IX. In: Cultura Política - Revista Mensal de Estudos Brasileiros, n. XIV, 1942. p.238-239.

- VIEIRA PINTO, Álvaro. Considerações sobre a lógica do antigo estoicismo. In: Revista da Faculdade Nacional de Filosofia, v. 1. Rio de Janeiro: Faculdade Nacional de Filosofia da Universidade do Brasil, 1949. p.56-79. ${ }^{156}$

- VIEIRA PINTO, Álvaro. Ensaio sobre a Dinâmica na Cosmologia de Platão. (Tese para a Cátedra de História da Filosofia) Rio de Janeiro: Faculdade Nacional de Filosofia da Universidade do Brasil, 1949.

- VIEIRA PINTO, Álvaro. Note sur la traduction de Platon, Timée 43 b. In: Revue des Études Grecques, v. 65, n. 306-308. Paris, jul./dez 1952. p.469-473.

- VIEIRA PINTO, Álvaro. Ideologia e Desenvolvimento Nacional. Ministério da Educação e Cultura (MEC) / Instituto Superior de Estudos Brasileiros (ISEB), 1956. $48 \mathrm{p}$.

- VIEIRA PINTO, Álvaro. Ideologia e Desenvolvimento Nacional. $2^{\mathrm{a}}$ ed. Rio de Janeiro: Ministério da Educação e Cultura (MEC) / Instituto Superior de Estudos Brasileiros (ISEB), 1959. (Textos Brasileiros de Filosofia, 4).

- VIEIRA PINTO, Álvaro. Ideologia e Desenvolvimento Nacional. $3^{\mathrm{a}}$ ed. Rio de Janeiro: Ministério da Educação e Cultura (MEC) / Instituto Superior de Estudos Brasileiros (ISEB), 1959. (Textos Brasileiros de Filosofia, 4)

- VIEIRA PINTO, Álvaro. Ideologia e Desenvolvimento Nacional. $4^{\mathrm{a}} \mathrm{ed}$. Rio de Janeiro: Ministério da Educação e Cultura (MEC) / Instituto Superior de Estudos Brasileiros (ISEB), 1960. 54 p. (Textos Brasileiros de Filosofia, 4) ${ }^{157}$

- VIEIRA PINTO, Álvaro. Ideología y desarrollo nacional. Centro Interamericano de Desarrollo Rural y Reforma Agraria: Bogotá, 1969. 17 p. 28 $\mathrm{cm}$. Mimeografado. 
- VIEIRA PINTO, Álvaro. Filosofía Actual. Asunción, Paraguay: Misión Cultural Brasileña, 1957. 146 p. Mimeografado.

- VIEIRA PINTO, Álvaro. Introdução. In: JASPERS, Karl. Razão e anti-razão em nosso tempo. Tradução por Álvaro Vieira Pinto. Rio de Janeiro: Instituto Superior de Estudos Brasileiros (ISEB), 1958. (Coleção Textos de Filosofia Contemporânea, 1)

- VIEIRA PINTO, Álvaro. Prefácio. In: DEBRUN, Michel. Ideologia e Realidade. Rio de Janeiro: Instituto Superior de Estudos Brasileiros (ISEB), 1959. (Coleção Textos Brasileiros de Filosofia, 5)

- VIEIRA PINTO, Álvaro. Consciência e Realidade Nacional. Rio de Janeiro: Instituto Superior de Estudos Brasileiros (ISEB), 1960. 2 v. (Coleção Textos Brasileiros de Filosofia, 1) ${ }^{158}$

- VIEIRA PINTO, Álvaro. A Questão da Universidade. Rio de Janeiro: UNE/Editôra Universitária, 1962. (Cadernos Universitários, 1) ${ }^{159}$

- VIEIRA PINTO, Álvaro. A Questão da Universidade. São Paulo: Cortez Editora: Autores Associados, 1986. (Coleção Educação Contemporânea)

- VIEIRA PINTO, Álvaro. A Questão da Universidade. $2^{a}$ ed. São Paulo: Cortez Editora, 1994. (Coleção Educação Contemporânea)

- VIEIRA PINTO, Álvaro. Porque os ricos não fazem greve? Rio de Janeiro: Civilização Brasileira, 1962. 120 p. (Cadernos do Povo Brasileiro, 4)

- VIEIRA PINTO, Álvaro. Os ricos não fazem greve - porquê? $1^{\mathrm{a}}$ ed. Portugal: Editora DiAbril, 1975. 110 p. (Coleção Universidade do Povo, 4)

- VIEIRA PINTO, Álvaro. Indicações metodológicas para a definição do subdesenvolvimento. In: Revista Brasileira de Ciências Sociais, v. III, n. 2 (jul). Belo Horizonte: Faculdade de Ciências Econômicas da Universidade de Minas Gerais, 1963. p.252-279.

- VIEIRA PINTO, Álvaro. El Pensamiento Critico en Demografia. Santiago de Chile: Centro Latinoamericano de Demografia (CELADE), 1973. 449 p. (Série E, 8)

- VIEIRA PINTO, Álvaro. La Demografía como Ciencia. Santiago de Chile: Centro Latinoamericano de Demografía (CELADE), 1975. 30 p. (Série Textos de Divulgación, 1)

- VIEIRA PINTO, Álvaro. Ciência e Existência: Problemas filosóficos da pesquisa científica. Rio de Janeiro: Paz e Terra, 1969. (Série Rumos da Cultura Moderna, 20)

- VIEIRA PINTO, Álvaro. Ciência e Existência: Problemas filosóficos da pesquisa científica. $2^{\mathrm{a}}$ ed. Rio de Janeiro: Paz e Terra. 1979. (Série Rumos da Cultura Moderna, 20; Coleção Pensamento Crítico, 7)

- VIEIRA PINTO, Álvaro. Ciência e Existência: Problemas filosóficos da pesquisa científica. $3^{\mathrm{a}}$ ed. Rio de Janeiro: Paz e Terra, 1985. (Série Rumos da Cultura Moderna, 20; Coleção Pensamento Crítico, 7)

- VIEIRA PINTO, Álvaro. Sete lições sobre educação de adultos. São Paulo: Autores Associados: Cortez, 1982.

- Em levantamento realizado a partir de referências bibliográficas, temos os seguintes anos das edições: 1982, 1984 ( $2^{\mathrm{a}}$ ed.), 1985 ( $3^{\mathrm{a}}$ ed.), 1986 ( $4^{\mathrm{a}}$ ed.), 1987 ( $5^{\text {a }}$ ed.), 1989 (6 ${ }^{\mathrm{a}}$ ed.), 1991 ( $7^{\mathrm{a}}$ ed. $), 1993$ ( $8^{\mathrm{a}}$ ed. $), 1994$ ( $9^{\mathrm{a}}$ ed. $), 1997$ 


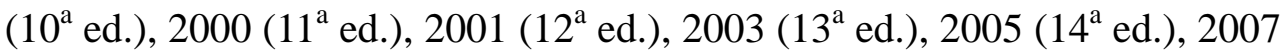
(15 ed.), 2010 (16 ${ }^{\mathrm{a}}$ ed.).

- VIEIRA PINTO, Álvaro. Sete lições sobre educação de adultos. $16^{\mathrm{a}}$ ed. São Paulo: Cortez, 2010.

- VIEIRA PINTO, Álvaro. O Conceito de Tecnologia. Rio de Janeiro: Contraponto, 2005.2 v. $^{160}$

○ Reimpressões: jun. 2008 ( $1^{\mathrm{a}}$ reimpr.), out. 2013 ( $2^{\mathrm{a}}$ reimpr.). ${ }^{161}$

- VIEIRA PINTO, Álvaro. A Sociologia dos Países Subdesenvolvidos: Introdução metodológica ou prática metodicamente desenvolvida da ocultação dos fundamentos sociais do "vale das lágrimas". Rio de Janeiro: Contraponto, 2008. ${ }^{162}$

Como tradutor, Vieira Pinto traduziu na década de 1950:

- VIEIRA PINTO, Álvaro. O Poema de Parmênides: Tradução literal sobre o têxto grego, segundo Mullach. In: Diretório Acadêmico da Faculdade Nacional de Filosofia da Universidade do Brasil, Rio de Janeiro, mar. 1951. p.11-15.

- JASPERS, Karl. Razão e anti-razão em nosso tempo. Tradução por Álvaro Vieira Pinto. Rio de Janeiro: Instituto Superior de Estudos Brasileiros (ISEB), 1958. (Coleção Textos de Filosofia Contemporânea, 1)

No exílio traduz:

- SMULEVICH, B. Ia. Críticas de las teorías y la política burguesas de la población. Tradução por Álvaro Vieira Pinto. Santiago de Chile: Centro Latinoamericano de Demografía (CELADE), 1971. 483 p. (Série E., 7)

Ao retorno ao Brasil, foram 20 traduções realizadas para a Editora Vozes, de 1970 a 1978, algumas com várias reimpressões, referência que optamos por omitir neste texto. Em ordem cronológica da primeira edição:

- CLARKE, Arthur C. Perfil do Futuro. Tradução por Álvaro Borges Vieira Pinto. Petrópolis, RJ: Vozes, 1970. (Coleção Presença do Futuro, 4)

- RAPP, Hans Reinhard. Cibernética e Teologia: O Homem, Deus e o Número. Tradução por Francisco M. Guimarães (pseudônimo de Álvaro Vieira Pinto). Petrópolis, RJ: Vozes, 1970.

- TOYNBEE, Arnold Joseph. Experiências: Ensaio autobiográfico de um dos maiores historiadores do século XX. Tradução por Francisco M. Guimarães (pseudônimo de Álvaro Vieira Pinto). Petrópolis, RJ: Vozes, 1970.

- CHURCHMAN, C. West. Introdução à Teoria Dos Sistemas. Tradução por Francisco M. Guimarães (pseudônimo de Álvaro Vieira Pinto). Petrópolis, RJ: Vozes, 1971. (Coleção Teoria Dos Sistemas, 1$)^{163}$

- CHOMSKY, Noam. Linguagem e Pensamento. Tradução por Francisco M. Guimarães (pseudônimo de Álvaro Vieira Pinto). $2^{\mathrm{a}}$ ed. Petrópolis, RJ: Vozes, 1971. (Coleção Perspectivas Linguísticas, 3$)^{164}$

- CHOMSKY, Noam. Lingüística Cartesiana: Um capítulo da história do pensamento racionalista. Tradução por Francisco M. Guimarães (pseudônimo de Álvaro Vieira Pinto). Petrópolis, RJ: Vozes, 1972. (Coleção Perspectivas Linguísticas, 4)

- POSTGATE, John Raymond. Os Micróbios e o Homem. Tradução por Francisco M. Guimarães (pseudônimo de Álvaro Vieira Pinto). Petrópolis, RJ: Vozes, 1971. (Coleção Ciência Atual, 1) 
- DAJOZ, Roger. Ecologia Geral. Tradução por Francisco M. Guimarães (pseudônimo de Álvaro Vieira Pinto). Petrópolis, RJ: Vozes, $1972 .{ }^{165}$

- GÉRARD, Pierre. Introdução Ao Marketing. Tradução por Francisco M. Guimarães (pseudônimo de Álvaro Vieira Pinto). Petrópolis, RJ: Vozes, 1973. (Coleção Administração de Empresas)

- APTER, M. J. Cibernética e Psicologia. Tradução de Francisco M. Guimarães (pseudônimo de Álvaro Vieira Pinto). Petrópolis, RJ: Vozes, 1973.

- MALINOWSKI, Bronislaw. Sexo e Repressão na Sociedade Selvagem. Tradução por Francisco M. Guimarães (pseudônimo de Álvaro Vieira Pinto). Petrópolis, RJ: Vozes, 1973. (Coleção Antropologia) ${ }^{166}$

- LAWRENCE, Paul R.; LORSCH, Jay William. As Empresas e o Ambiente: diferenciação e integração administrativas. Tradução por Francisco M. Guimarães (pseudônimo de Álvaro Vieira Pinto). Petrópolis, RJ: Vozes, 1973. (Coleção Administração de Empresas, 9)

- PIAGET, Jean. Biologia e Conhecimento: ensaio sobre as relações entre as regulações orgânicas e os processos cognoscitivos. Tradução por Francisco M. Guimarães (pseudônimo de Álvaro Vieira Pinto). Petrópolis, RJ: Vozes, 1973. (Coleção Psicologia da Inteligência, 1) ${ }^{167}$

- BERGER, Peter L.; LUCKMANN, Thomas. A Construção Social da Realidade: Tratado de Sociologia Do Conhecimento. Tradução por Floriano de Souza Fernandes (pseudônimo de Álvaro Vieira Pinto). Petrópolis, RJ: Vozes, 1973. (Coleção Antropologia, 5) ${ }^{168}$

- BertalanfFy, Ludwig Von. Teoria Geral Dos Sistemas. Tradução por Francisco M. Guimarães (pseudônimo de Álvaro Vieira Pinto). Petrópolis, RJ: Vozes, 1972. (Coleção Teoria Dos Sistemas, 2) ${ }^{169}$

- KANT, Immanuel. Textos seletos. Tradução de Floriano de Sousa Fernandes (pseudônimo de Álvaro Vieira Pinto) e Raimundo Vier. Petrópolis: Vozes, $1974 .^{170}$

- LOURAU, René. A Análise Institucional. Petrópolis, RJ: Vozes. Tradução por Mariano Ferreira (pseudônimo de Álvaro Vieira Pinto), 1975. (Coleção Psicanálise, $12) .{ }^{171}$

- ROGIER, L. J.; BERTIER DE SAUVignY, L. B. F. de. Nova História da Igreja. Volume 5: A igreja na sociedade liberal e no mundo moderno. Tradução de Almir Ribeiro Guimarães; Floriano de Souza Fernandes (pseudônimo de Álvaro Vieira Pinto). Petrópolis, RJ: Vozes, 1975.

- LÉVI-STRAUSS, Claude. As Estruturas Elementares do Parentesco. Roberto Augusto da Matta (Editor). Tradução por Mariano Ferreira (pseudônimo de Álvaro Vieira Pinto). Petrópolis, RJ: Vozes, 1976. (Coleção Antropologia, 9). ${ }^{172}$

- VAN GENNEP, Artur. Os Ritos de Passagem. Tradução por Mariano Ferreira (pseudônimo de Álvaro Vieira Pinto). Petrópolis, RJ: Vozes, 1978. (Coleção Antropologia, 11). ${ }^{173}$

Existe ainda uma tradução, não disponível, solicitada pela Editora Civilização Brasileira à Vieira Pinto, que foi impressa, mas recolhida e destruída antes da distribuição:

- LENIN, Vladimir Ilitch. Obras Escolhidas de Lenin. Tradução por Álvaro Vieira Pinto. 3 vol. Rio de Janeiro: Editora Civilização Brasileira, 1970. 


\section{Agradecimentos}

Agradecemos à atriz Mariza Urban pela disponibilidade em nos atender, ao seu neto Derek Urban pelo contato, e a ambos pela atenção e apoio a este projeto. Também agradecemos à professora Norma Côrtes e ao arquiteto Manuel Rivarola Mernes por nos viabilizar a consulta e o acesso à tese de Álvaro Vieira Pinto e a apostila de seu curso no Paraguai. Agradecemos a ajuda com informações e trocas de referências que nos ofereceu Sandra Andréia Ferreira, nossa colega de pesquisa no PPGTE da UTFPR de Curitiba, que em sua investigação de mestrado realizou o levantamento da presença de Vieira Pinto na mídia impressa da época, junto ao acervo digital da Biblioteca Nacional e outras fontes. Agradecemos especialmente a Gilson Leandro Queluz e a Tiago Brandão pela revisão do texto e pelas sugestões.

\section{Referências ${ }^{174}$}

CHEDID, Daniele Reiter; MORAES, Ceres. A missão cultural brasileira no Paraguai: uma relação política bilateral. In: III Seminário Internacional de História: Instituições, Fronteiras e Política na História Sul-Americana. CD-Anais, v.1, Maringá, 2007. Disponível em: 〈http://www.pph.uem.br/iiisih/pdf/118.pdf>.

COLÉGIO SANTO INÁCIO (Website). Relação de ex-alunos do CSI (Colégio Santo Inácio) (29.768). Disponível em: 〈http://www.oocities.org/excsi/EXALUNOS.HTM>.

CÔRTES, Norma. O filósofo e o historiador - dois homens e um destino. In: CUNHA, Paulo Ribeiro da; CABRAL, Fátima (Org.). Nelson Werneck Sodré: entre o sabre e a pena. São Paulo: Editora da UNESP, 2006. p.295-312.

CÔRTES, Norma. Esperança e democracia: as idéias de Álvaro Vieira Pinto. Rio de Janeiro: Iuperj; Belo Horizonte: Ed. UFMG, 2003.

DEPARTAMENTO ADMINISTRATIVO DO PESSOAL CIVIL PROCESSO N.o 6.054/68 (de 16 de fevereiro de 1971). Biblioteca Digital da FGV. Disponível em: <http://bibliotecadigital.fgv.br/ojs/index.php/rda/article/viewFile/36467/35236>.

FÁVERI, José Ernesto de (Org.). O Legado de Álvaro Vieira Pinto na voz de seus contemporâneos. Blumenau: Nova Letra, 2012.

FÁVERI, José Ernesto de. Álvaro Vieira Pinto: Contribuições à educação libertadora de Paulo Freire. São Paulo: LiberArs, 2014.

FERREIRA, J. C. P.; ALMEIDA, M. A.; FERNANDES, M. O.; SENRA, M. (Orgs.). Editando $O$ Editor 3 - Ênio Silveira. São Paulo: Editora da Universidade de São Paulo; ComArte, 2003.

FREITAS, Marcos Cezar de. Economia e educação: a contribuição de Álvaro Vieira Pinto para o estudo histórico da tecnologia. In: Revista. Brasileira de Educação, Rio de Janeiro, v.11, n.31, abr. 2006. Disponível em $<$ http://ref.scielo.org/fwh3qz $>$.

FREITAS, Marcos Cezar de. Álvaro Vieira Pinto: A personagem histórica e sua trama. São Paulo: Cortez. USF-IFAN. 1998.

FREITAS, Marcos Cezar de. O conceito de tecnologia: O quarto quadrante do círculo de Álvaro Vieira Pinto. In: VIEIRA PINTO, Álvaro. O Conceito de Tecnologia. $1^{\circ}$ vol. p.125. Rio de Janeiro: Contraponto, 2005.

LIMA, Michelle Fernandes. Álvaro Borges Vieira Pinto na Esquerda Brasileira (19611964). In: Revista Café com Sociologia. v.4, n.1, jan-abr, 2015. Disponível em: 〈http://revistacafecomsociologia.com/revista/index.php/revista/article/view/433〉. 
LOVATTO, Angélica. O pensamento de Nelson Werneck Sodré nos Cadernos do Povo Brasileiro. In: CUNHA, Paulo Ribeiro da; CABRAL, Fátima (Org.). Nelson Werneck Sodré: entre o sabre e a pena. São Paulo: Editora da UNESP, 2006. p.313-326. Disponível em: $\quad<$ http://marxismo21.org/wp-content/uploads/2012/09/conceito-de-povo-emSodr\%C3\%A9-nos-CPB-A-Lovatto.pdf $>$.

MAURO, José. Satrre Visitou o Morro da Babilônia. (Coluna "Na Hora H", seção "Sete notícias"). Jornal Última Hora, Rio de Janeiro, p.3, 30 ago. 1960. Disponível em: <http://memoria.bn.br/DocReader/DocReader.aspx?bib=386030\&PagFis=61578 > .

MELO, Demian Bezerra de. O plebiscito de 1963: Inflexão de forças na crise orgânica dos anos sessenta. Dissertação (Programa de Pós-Graduação em História da Universidade Federal Fluminense). Niterói, 2009. Disponível em: <http://www.historia.uff.br/stricto/teses/Dissert-2009_Demian_Bezerra_de_Melo-S.pdf $>$.

MORAES, Ceres. Paraguai: a consolidação da ditadura de Stroessner, 1954-1963. Coleção História. Porto Alegre: EDIPUCRS, 2000.

MORAES AUGUSTO, Maria das Graças de. Álvaro Vieira Pinto e a verossimilhança do mythos (Introdução). In: Kléos, n.13/14: 113/143, 2009/10, Rio de Janeiro, p.113-117. Disponível em: <http://www.pragma.ifcs.ufrj.br/kleos/K13/K13-AlvaroPinto.pdf>

MORAES, Vinícius de. A letra A: Palavra por Palavra (IV). In: Jornal do Brasil. Rio de Janeiro. 31 de dezembro de 1969. Disponível em: <http://www.viniciusdemoraes.com.br/pt-br/prosa/jornais/letra-palavra-por-palavra-iv $>$.

MORAES, Vinícius de. Vinícius: Palavra por Palavra. In: Jornal do Commercio (Caderno Cad 2) Manaus, 24 de junho de 1973. p.9. Disponível em: <http://memoria.bn.br/DocReader/DocReader.aspx?bib=170054_01\&PagFis=106879>.

PEREIRA, Osny Duarte Pereira. No cinqüentenário da Constituição de 1946, a defesa da carta na posse de Café Fillho. In: Revista de Sociologia e Política, n.6/7, 1996. Disponível em: 〈http://ojs.c3sl.ufpr.br/ojs/index.php/rsp/article/viewFile/39338/24154>.

PAIVA, Vanilda Pereira. Paulo Freire e o nacionalismo-desenvolvimentista. Rio de Janeiro: Editora Civilização Brasileira, 1980.

PROEDES. Arquivo Faculdade Nacional de Filosofia - FNFi. 2015. Disponível em: <http://www.fe.ufrj.br/proedes/arquivo/fnfi.htm>.

RODRIGO, Lídia Maria. O nacionalismo no pensamento filosófico. Petrópolis: Vozes, 1988.

ROUX, Jorge. Álvaro Vieira Pinto: Nacionalismo e Terceiro Mundo. São Paulo: Cortez, 1990.

\footnotetext{
1 Texto também publicado em forma de capítulo, com título "Vida e obra de Álvaro Borges Vieira Pinto: levantamento biobibliográfico", no livro "Pensamentos e Identidades em Ciência e Tecnologia no Mundo Iberoamericano", organizado por Gilson Queluz e Tiago Brandão, do grupo de pesquisa Ciências Humanas, Tecnologia e Sociedade (CHTS). Alterações pontuais foram realizadas para esta publicação.

2 Paulo Freire cita Álvaro Vieira Pinto em pelo menos 11 obras, segundo levantamento realizado por nós disponível em: 〈http://www.alvarovieirapinto.org/debates/paulo-freire-citando-alvaro-vieira-pinto/>.

3 Ressaltamos que ainda não conseguimos acesso a todas as publicações mencionadas, e que outras tem publicamente o paradeiro incerto, o que caracteriza esta biobibliografia com um trabalho em andamento. Algumas destas infere-se a existência, como alguns números da revista Pelo Brasil.

4 As obras que estão sendo comercializadas em livrarias atualmente são: "O Conceito de Tecnologia" e "A Sociologia dos Países Subdesenvolvidos", estas duas publicadas pela Editora Contraponto (a partir de manuscritos inéditos do autor encontrados); "Sete lições sobre Educação de adultos", atualmente em sua 16a edição, editada pela Editora Cortez; e "Ideologia e Desenvolvimento Nacional", livro republicado como capítulo na obra "Brasil de João Goulart, O: um projeto de nação", pela Editora Contraponto.
} 


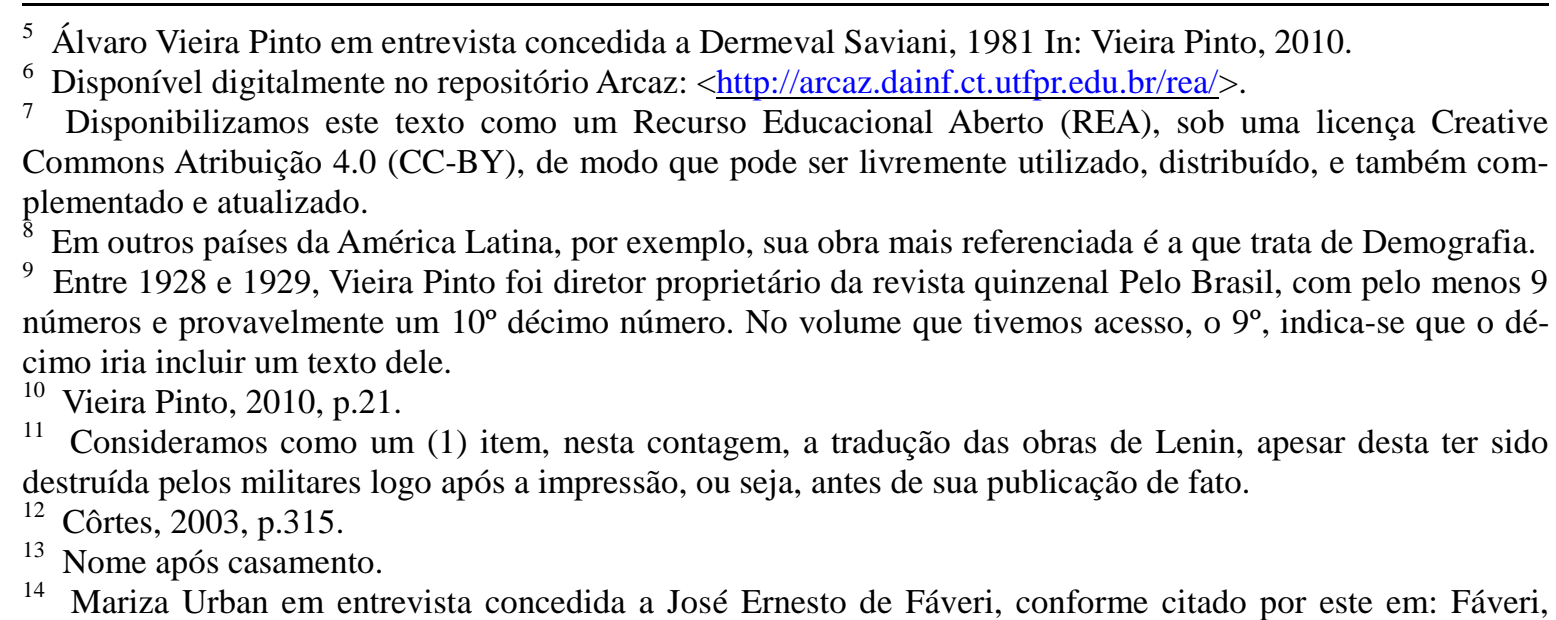
2014, p.93; Informações sobre os sobrenomes consultada em: Colégio Santo Inácio, 2015.

${ }_{15}$ Saviani, Dermeval; 1981 In: Vieira Pinto, 2010, p.22.

${ }^{16}$ Existem indicações que Álvaro Vieira Pinto e Vinícius de Moraes foram amigos e se conheceram na infância. Ambos fizeram curso secundário no colégio Santo Inácio. Em suas memórias, no texto "A letra A: Palavra por Palavra (IV)", verbete 'Abismo' (Moraes, 1969) publicado no Jornal do Brasil (em 31/12/1969), o poeta comenta sobre um momento (aos 13 anos) de sua amizade com A.V.P. Apesar do texto disponível online manter a grafia "A.V.P.", em outra versão deste texto (Moraes, 1973) consta: "um colega, o Álvaro Vieira Pinto (que, aliás, se tornou um cientista muito conhecido) (...) E o que o Álvaro disse era novo, foi mesmo a primeira experiência de fraternidade."

${ }_{17}^{17}$ Fáveri, 2014, p.93.

${ }_{18}^{18}$ Dermeval Saviani, 1981 In: Vieira Pinto, 2010, p.14.

${ }^{19}$ Fáveri, 2014, p.94.

20 Álvaro Vieira Pinto em entrevista concedida a Dermeval Saviani, 1981 In: Vieira Pinto, 2010, p.13.

21 Álvaro Vieira Pinto em entrevista concedida a Dermeval Saviani, 1981 In: Vieira Pinto, 2010, p.13. Supomos que dentre estes estejam Augusto Frederico Schmidt, que trabalhou para Carlos V. Pinto como caixeiro viajante, e Hamilton Nogueira. Segundo Mariza Urban, sobrinha de Vieira Pinto, Schmidt foi criado por pela família de Vieira Pinto, mas depois se distanciaram.

${ }_{22}$ Côrtes, 2003, p.315.

${ }^{23}$ Publicação mensal, laureada pela academia Brasileira de Letras, de textos completos e inéditos de literatura regional contemporânea

${ }^{24}$ Vieira Pinto também foi proprietário da marca desta revista. No Jornal Correio da Manhã, 26 de agosto de 1930. p.12, Seção "A Vida Commercial", Coluna "Directoria Geral da Propriedade Industrial - Expediente do Sr. Director Geral" $\langle$ http://memoria.bn.br/DocReader/DocReader.aspx?bib=089842_04\&PagFis=3546 $>$, consta: "São convidados a comparecer nesta Directoria Geral, afim de satisfazerem na Recebedoria do Districto Federal, mediante expedição da respectiva guia, o pagamento das taxas de suas marcas, mandadas a registro de acordo com os artigos 98 e 108 letra B, do regulamento annexo ao decreto n. 16.264, de 19 de dezembro de 1923, os seguintes interessantes: (...) Alvaro Vieira Pinto, marca Pelo Brasil;"

${ }^{25}$ Até o momento, em nossa pesquisa, encontramos apenas 3 edições desta revista (números 3,5 e 9), editadas em 1928 e 1929.

${ }^{26}$ Existe referência a um texto de Vieira Pinto em uma das edições futuras, a $10^{\mathrm{a}}$, ainda não encontrada.

${ }^{27}$ Até o momento, em nossa pesquisa, apenas estes textos de Vieira Pinto foram identificados nesta revista.

${ }^{28}$ Côrtes, 2003, p.316.

29 Várias destas informações tem por fontes a chamadas a exames e provas publicadas em jornais da época.

Não incluiremos as referências neste texto, por limitações de espaço.

${ }^{30}$ Côrtes, 2003, p.316.

31 Álvaro Vieira Pinto em entrevista concedida a Dermeval Saviani, 1981 In: Vieira Pinto, 2010, p.13.

${ }^{32}$ Fáveri, 2014, p.94; Côrtes, 2003, p.316.

33 Álvaro Vieira Pinto em entrevista concedida a Dermeval Saviani, 1981 In: Vieira Pinto, 2010, p.13.

${ }^{34}$ Côrtes, 2003, p.316.

35 Álvaro Vieira Pinto em entrevista concedida a Dermeval Saviani, 1981 In: Vieira Pinto, 2010, p.11.

${ }^{36}$ Côrtes, 2003, p.316; Vieira Pinto, 1941 [I].

37 Álvaro Vieira Pinto em entrevista concedida a Dermeval Saviani, 1981 In: Vieira Pinto, 2010, p.16-17.

38 Jornal Vida, n.2, maio de 1934, p.6. Disponível em:

$<$ http://memoria.bn.br/DocReader/DocReader.aspx?bib=720062\&PagFis=22 >. O I. C. E. S., iniciativa do 
Centro Dom Vidal, foi o núcleo que viabilizou a criação das Faculdades Católicas, que deram origem as Universidades Católicas.

39 Côrtes, 2003, p.316; Freitas, 1998, p.47.

40 Álvaro Vieira Pinto em entrevista concedida a Dermeval Saviani, 1981 In: Vieira Pinto, 2010, p.16-17.

41 Álvaro Vieira Pinto em entrevista concedida a Dermeval Saviani, 1981 In: Vieira Pinto, 2010, p.11.

42 Apresentação do autor In: Vieira Pinto, 1941 [I], p.265; Fáveri, 2014, p.95; Álvaro Vieira Pinto em entrevista concedida a Dermeval Saviani, 1981 In: Vieira Pinto, 2010, p.14-15.

43 Procedes, 2015; Álvaro Vieira Pinto em entrevista concedida a Dermeval Saviani, 1981 In: Vieira Pinto, 2010, p.11.

44 Evaristo de Moraes Filho In: Moraes Augusto, 2009/10, p.115; Álvaro Vieira Pinto em entrevista concedida a Dermeval Saviani, 1981 In: Vieira Pinto, 2010, p.11; Moraes Augusto, 2009/10, p.114.

45 Álvaro Vieira Pinto em entrevista concedida a Dermeval Saviani, 1981 In: Vieira Pinto, 2010, p.11; Evaristo de Moraes Filho In: Moraes Augusto, 2009/10, p.115; Moraes Augusto, 2009/10, p.114.

46 Fáveri, 2014, p.95.

47 Côrtes, 2003, p.317-318.

48 Álvaro Vieira Pinto em entrevista concedida a Dermeval Saviani, 1981 In: Vieira Pinto, 2010, p.14.

49 Moraes Augusto, 2009/10, p.115.

50 Álvaro Vieira Pinto em entrevista concedida a Dermeval Saviani, 1981 In: Vieira Pinto, 2010, p.14-15.

51 Côrtes, 2003, p.318.

52 Segundo Vieira Pinto, 1949, p 36, ocupou a cátedra de Filosofia Grega na Sorbonne a convite do professor Pierre Maxime Schuhl, para expor aos estudantes as ideias contidas em sua tese, à época em elaboração.

53 Conforme cita Moraes Augusto, 2009/10, p.115-116.

54 Moraes Augusto, 2009/10, p.115.

55 Álvaro Vieira Pinto em entrevista concedida a Dermeval Saviani, 1981 In: Vieira Pinto, 2010, p.15.

56 Moraes Augusto, 2009/10, p.115. Álvaro Vieira Pinto em entrevista concedida a Dermeval Saviani, 1981, aponta a data como sendo 1951, em vez de 1950. Entretanto, no texto da Tese encontra-se a data de maio de 1949.

57 Álvaro Vieira Pinto em entrevista concedida a Dermeval Saviani, 1981 In: Vieira Pinto, 2010, p.14-15.

58 Fáveri, 2014, p.95.

59 Côrtes, 2003, p.318.

${ }^{60}$ Segundo Norma Côrtes (2003, p.318), esta abordagem se "inscreve na tradição da escola histórica alemã e está filiada às tentativas heideggerianas de estabelecer uma linguagem mais fidedigna do texto filosófico relativo ao seu contexto histórico."

61 Côrtes, 2003, p.318.

62 Álvaro Vieira Pinto em entrevista concedida a Dermeval Saviani, 1981 In: Vieira Pinto, 2010, p.17.

63 Álvaro Vieira Pinto em entrevista concedida a Dermeval Saviani, 1981 In: Vieira Pinto, 2010, p.14-15, 17; Côrtes, 2003, p.318.

${ }^{64}$ Moraes Augusto, 2009/10, p.114.

65 Álvaro Vieira Pinto em entrevista concedida a Dermeval Saviani, 1981 In: Vieira Pinto, 2010, p.17-18.

66 Álvaro Vieira Pinto em entrevista concedida a Dermeval Saviani, 1981 In: Vieira Pinto, 2010, p.14-15; Côrtes, 2003, p.318.

67 Moraes Augusto, 2009/10, p.116; Côrtes, 2003, p.318.

68 Côrtes, 2003, p.318.

${ }^{69}$ Moraes Augusto, 2009/10, p.117.

70 Jornal "A manhã". Atos e Despachos do Presidente da República. 6 set. 1951. p.4. Disponível em: <http://memoria.bn.br/DocReader/DocReader.aspx?bib=116408\&PagFis=53584>.

71 Jornal "A manhã". Atos e Despachos do Presidente da República. 31 ago. 1951. p.4. Disponível em: <http://memoria.bn.br/DocReader/DocReader.aspx?bib=116408\&PagFis=54684>.

72 Jornal "O Malho". De mês a mês. ano L, n.155. dez. 1952. p.24. Disponível em: <http://memoria.bn.br/DocReader/docreader.aspx?bib=116300\&PagFis=103081 >. Jornal "Correio da manhã", Vida Cultural. 18 de novembro de 1952, p.11. Disponível em: <http://memoria.bn.br/DocReader/DocReader.aspx?bib=089842_06\&PagFis=21946>.

73 Chedid e Moraes, 2007; Moraes, 2000.

74 Fáveri, 2014, p.99.

75 Côrtes, 2003, p.319.

76 Vários jornais informam essa autorização, porém, não encontramos referências se Vieira Pinto chegou a efetivá-la. Jornal do Brasil. Diversas Notícias. 20 de abril de 1954, p.6 (seção "Diversas Notícias"). Disponível em: 〈http://memoria.bn.br/DocReader/DocReader.aspx?bib=030015 07\&PagFis=39566>. Jornal "Correio da Manhã”. Um brasileiro na Universidade de La Paz. 20 de abril de 1954 (1 caderno), p.2. Disponível 
em: <http://memoria.bn.br/DocReader/DocReader.aspx?bib=089842 06\&PagFis=35737>. Jornal "A Noite". Cadeira de Estudos Brasileiros na Universidade de la Paz. Rio de Janeiro, 20 de abril de 1954. p.7. Disponível em: 〈http://memoria.bn.br/DocReader/DocReader.aspx?bib=348970 05\&PagFis=23947> .

${ }^{77}$ Freitas, 2006; Fávero, M. de L. A. Faculdade Nacional de Filosofia. Rio de Janeiro: UFRJ FUJB, 1992. v. 5, p.247-248 apud Moraes Augusto, 2009/10, p.115.

78 Álvaro Vieira Pinto em entrevista concedida a Dermeval Saviani, 1981 In: Vieira Pinto, 2010, p.18-19; Fáveri, 2014, p.96-97.

79 Álvaro Vieira Pinto em entrevista concedida a Dermeval Saviani, 1981 In: Vieira Pinto, 2010, p.18-19.

${ }^{80}$ Fáveri, 2014, p.94; Dermeval Saviani, 1982 In: Vieira Pinto, 2010, p.12.

${ }^{81}$ Vieira Pinto, 1956, p.7; Côrtes, 2004, p.319.

82 Côrtes, 2006, p.298-299.

83 "Lefêvre" (sic) é a grafia do nome encontrada no livro.

${ }^{84}$ Côrtes, 2006, p.299; Programação de publicação da Introdução escrita por Vieira Pinto In: Jaspers, 1958.

${ }^{85}$ Fáveri, 2014, p.99.

${ }^{86}$ Côrtes, 2003, p.32; Fáveri, 2014, p.99.

${ }^{87}$ Côrtes, 2003, p.32.

88 Côrtes, 2003, p.320.

${ }^{89}$ Lima, 2015.

${ }^{90}$ Fáveri, 2014, p.99

91 Álvaro Vieira Pinto em entrevista concedida a Dermeval Saviani, 1981 In: Vieira Pinto, 2010, p.22.; Fáveri, 2014, p.99; Introdução de Demerval Saviani escrita em dez. 1985 apud Vieira Pinto, 1986, p.5.

92 A segunda edição de "A questão da Universidade" é lançada apenas em 1994, publicada pela Editora Cortez ("Coleção Educação Contemporânea").

${ }^{93}$ Côrtes, 2003, p.320.

${ }^{94}$ Lovatto, 2006, p.315.

${ }^{95}$ Lovatto, 2006, p.314-315.

${ }^{96}$ Melo, 2009, p.162.

${ }_{97}$ Pereira, 1996, p.60-61; Melo, 2009, p.164-165.

98 Jornal "O Semanário". Porque votar contra o parlamentarismo no plebiscito?. n. 316.3 a 9 de janeiro de 1963. p.7. Disponível em: 〈http://memoria.bn.br/DocReader/DocReader.aspx?bib=149322\&PagFis=4323 >

99 Melo, 2009, p.162-163.

${ }^{100}$ Côrtes, 2003, p.320-321.

${ }^{101}$ Fáveri, 2014, p.99-100.

${ }^{102}$ Lima, 2015, p.102, p.108.

${ }^{103}$ Freitas, 1998, p.173-174.

${ }^{104}$ Lima, 2015.

${ }^{105}$ Roux, 1990.

${ }^{106}$ Fáveri, 2014, p.94, p.99-100.

${ }^{107}$ Côrtes, 2003, p.321.

${ }^{108}$ Lovatto, 2010, p.97.

109 Fáveri, 2014, p. 100.

110 Fáveri (2014, p.94), a partir de depoimento fornecido por Mariza Urban, comenta que muitos livros foram incinerados, inclusive com alguns manuscritos que Vieira Pinto estaria escrevendo.

${ }^{111}$ Côrtes, 2003, p.321.

112 Fáveri, 2014, p.94.

113 Ênio Silveira apud Côrtes, 2003, p.322.

${ }^{114}$ Fáveri, 2014, p.94; Dermeval Saviani, 1982 In: Vieira Pinto, 2010, p.11; Ênio Silveira apud Côrtes, 2003, p.322.

${ }_{115}$ Côrtes, 2003, p.322.

116 Álvaro Vieira Pinto em entrevista concedida a Dermeval Saviani, 1981 In: Vieira Pinto, 2010, p.19.

117 Álvaro Vieira Pinto em entrevista concedida a Dermeval Saviani, 1981 In: Vieira Pinto, 2010, p.16.

118 Álvaro Vieira Pinto em entrevista concedida a Dermeval Saviani, 1981 In: Vieira Pinto, 2010, p.21.

119 Álvaro Vieira Pinto em entrevista concedida a Dermeval Saviani, 1981 In: Vieira Pinto, 2010, p.19.

120 Álvaro Vieira Pinto em entrevista concedida a Dermeval Saviani, 1981 In: Vieira Pinto, 2010, p.19.

${ }^{121}$ Côrtes, 2003, p.322.

122 Côrtes, 2003, p.322; Documento de curriculum vitae da Dra. Aida Isabel Kirschbaum Kasten, elaborado em outubro de 2005, para a "Facultad de Medicina" da "Escuela de Salud Publica" da "Universidad de Chile": 〈http://www.uchile.cl/documentos/curriculum-vitae-dra-aida-kirschbaum-kasten 4008322 1822.pdf $>$

123 Álvaro Vieira Pinto em entrevista concedida a Dermeval Saviani, 1981 In: Vieira Pinto, 2010, p.20-21. 
124 Fáveri, 2014, p.100-101.

125 Álvaro Vieira Pinto em entrevista concedida a Dermeval Saviani, 1981 In: Vieira Pinto, 2010, p.20-21.

126 Fáveri, 2014, p.100-101; Fáveri, 2014, p.100-101.

127 Côrtes, 2003, p.322.

128 Dermeval Saviani, 1982 In: Vieira Pinto, 2010, p.11.

129 Álvaro Vieira Pinto em entrevista concedida a Dermeval Saviani, 1981 In: Vieira Pinto, 2010, p.20.

130 Fáveri, 2014, p.94, p.100.

131 Fáveri, 2014, p.100.

132 Côrtes, 2003, p.322.

133 Fáveri, 2014, p.101.

134 Dermeval Saviani, 1982 In: Vieira Pinto, 2010, p.11; Fáveri, 2014, p.101.

135 Segundo Fáveri (2014, p.101) são doze línguas. Segundo o próprio Álvaro Vieira Pinto, em entrevista concedida a Dermeval Saviani (1981 In: Vieira Pinto, 2010, p.15-16), são dez línguas: português, grego, latim, francês, inglês, alemão, russo, espanhol, italiano e sérvio-croata.

136 Fáveri, 2014, p.101; Côrtes, 2003, p.323.

137 Côrtes, 2003, p.323.

138 Fáveri, 2014, p.101.

139 Para detalhamento de informações, ver os seguintes sítios eletrônicos:

$<$ https://www.zotero.org/groups/alvaro_vieira_pinto/items/collectionKey/FITP44N5> e

$<$ http://www.alvarovieirapinto.org/traducoes/>.

140 Côrtes, 2003, p.323.

141 Ênio Silveira In: Ferreira et al., 2003, p.69-71.

142 Vieira Pinto, 2005, p.794.

143 Dermeval Saviani, 1982 In: Vieira Pinto, 2010, p.10-11.

144 Dermeval Saviani, 1982 In: Vieira Pinto, 2010, p.11-12.

145 Dermeval Saviani, 1982 In: Vieira Pinto, 2010, p.11; Documento do Departamento Administrativo Do Pessoal Civil Processo N.o 6.054/68 (de 16 de fevereiro de 1971), disponibilizado no site da Biblioteca Digital da FGV: 〈http://bibliotecadigital.fgv.br/ojs/index.php/rda/article/viewFile/36467/35236>.

146 Dermeval Saviani, 1982 In: Vieira Pinto, 2010, p.11; Côrtes, 2003, p.323.

147 Fáveri, 2014, p.101.

148 Côrtes, 2003, p.324; Fáveri, 2014, p.94.

149 Vieira Pinto, 1982.

150 Fáveri, 2014, p.101-102.

151 Fáveri, 2014, p.102.

152 Enlace para o sítio eletrônico: <http://arcaz.dainf.ct.utfpr.edu.br/rea/>.

153 Enlace para o sítio eletrônico: 〈https://www.zotero.org/groups/alvaro_vieira_pinto〉.

154 Enlace para o sítio eletrônico: <http://www.alvarovieirapinto.org/>.

$155 \mathrm{Na}$ plataforma Zotero, estão listadas todas as edições e reimpressões que conseguimos identificar, tanto de seus escritos como de suas traduções, como do trabalho de terceiros, sobre Vieira Pinto, ou com base nele.

156 Uma edição fac-similar deste texto foi publicada em: Kléos - Revista de filosofia antiga. Programa de

Estudos em Filosofia Antiga, Instituto de Filosofia e Ciências Sociais. Universidade Federal do Rio de Janeiro (UFRJ). v. 113/143, n. 13/14, Rio de Janeiro, 2009/10. p.119-143. Disponível em: 〈http://www.pragma.ifcs.ufrj.br/kleos/K13/K13-AlvaroPinto.pdf >

157 Uma edição fac-similar deste texto foi publicada em: Revista Estudos Políticos. Laboratório de Estudos

Hum(e)anos (UFF)/Núcleo de Estudos em Teoria Política (UFRJ). Rio de Janeiro, n. 6, jul. 2013. p.245-344. ISSN: 2177-2851. Disponível em:

〈http://revistaestudospoliticos.com/wp-content/uploads/2013/10/facsimile.pdf >

158 O $1^{\circ}$ volume publicado em setembro de 1960 e o $2^{\circ}$ volume em junho de 1961. (CÔRTES, 2003, p.320)

159 Existem diversas publicações com menções a uma edição de "A questão da Universidade" datada de 1961, porém não conseguimos acesso a esta.

160 Obra publicada postumamente a partir do manuscrito do autor, escrito em 1973 e revisado em 1974.

161 Sabe-se também da referência a uma edição de "O Conceito de Tecnologia" (2005) editada pelo BNDES

(Banco Nacional de Desenvolvimento Econômico e Social) pela Coleção "Os Desenvolvimentistas".

162 Obra publicada postumamente a partir do manuscrito do autor de 1975.

$1632^{\mathrm{a}}$ edição em 1972.

$1643^{\text {a }}$ edição em 1973; $4^{\mathrm{a}}$ edição em 1977.

$1653^{\text {a }}$ edição em 1973 e $1978 ; 4^{a}$ edição em 1983.

$1662^{a}$ edição em 2000; $3^{a}$ edição em 2013.

$1672^{a}$ edição em 1996; $3^{a}$ edição em 2000; $4^{a}$ edição em 2003. 
168 2 $2^{\mathrm{a}}$ edição em 1974; $3^{\mathrm{a}}$ edição em 1976; $4^{\mathrm{a}}$ edição em 1978; $5^{\mathrm{a}}$ edição em $1983 ; 6^{\mathrm{a}}$ edição em $1985 ; 7^{\mathrm{a}}$ edição em 1987; $8^{a}$ edição em 1990; $9^{a}$ edição em $1991 ; 10^{a}$ edição em $1993 ; 11^{a}$ edição em 1994; $12^{a}$ edição em 1995; $13^{a}$ edição em 1996; $14^{a}$ edição em 1997; 15ª e 16 a edição em 1998; $17^{a}$ edição em 1999; $19^{a}$ edição em 2000; $20^{a}$ edição em 2001; $21^{a}$ edição em 2002; $23^{a}$ edição em 2003 e 2004; $24^{a}$ edição em 2004; $25^{a}$ e $26^{a}$ edição em 2005; $27^{a}$ edição em 2007; $28^{a}$ e $29^{a}$ edição em 2008; $30^{a}$ e $31^{a}$ edição em 2009; $32^{a}$ edição em 2010; $33^{a}$ edição em 2011; $34^{a}$ edição em 2012; $35^{a}$ edição em 2012; 36a edição em 2014.

$1692^{\mathrm{a}}$ edição em 1975; $3^{\mathrm{a}}$ edição em 1977; $4^{\mathrm{a}}$ edição em 2009; $5^{\mathrm{a}}$ edição em 2010; $6^{\mathrm{a}}$ edição em $2012 ; 7^{\mathrm{a}}$ edição em 2013; 8 a edição em 2015.

$1702^{a}$ edição em 1985; $2^{a}$ edição em 2005; $4^{a}$ edição em 2008; $6^{a}$ edição em 2010; $8^{a}$ edição em 2012; $9^{a}$ edição em 2013.

$1712^{\mathrm{a}}$ edição em 1996; $3^{\mathrm{a}}$ edição em 2014.

$1722^{a}$ edição em 1982; $3^{a}$ edição em $2003 ; 4^{a}$ edição em 2008; $5^{a}$ edição em 2009; $6^{a}$ edição em $2011 ; 7^{a}$ edição em 2012

$1732^{\mathrm{a}}$ edição em 2011.

174 Todas as referências com enlaces para sítios eletrônicos foram acessadas em 16 de fevereiro de 2015.

Recebido: março/16 Aprovado: dezembro/16 